\title{
Inventário e avaliação quantitativa do patrimônio geológico de Bertioga (SP, Brasil)
}

\author{
Vanessa Costa MUCIVUNA, Maria da Glória Motta GARCIA \& Eliane Aparecida DEL LAMA
}

Universidade de São Paulo, Instituto de Geociências, Núcleo de Apoio à Pesquisa em Patrimônio Geológico e Geoturismo (GeoHereditas). Rua do Lago, 562, Térreo, Bloco D, Sala 11, CEP 05508-080, São Paulo, SP, Brasil (vanessa.mucivuna@usp. br, mgmgarcia@usp.br, edellama@usp.br).

Recebido em 05/2016. Aceito para publicação em 07/2017. Versão online publicada em 21/10/2017 (www.pesquisasemgeociencias.ufrgs.br)

\begin{abstract}
Resumo - Bertioga localiza-se no litoral do Estado de São Paulo e é reconhecida por notável geodiversidade. Por isso, este trabalho tem por objetivo discorrer sobre a abordagem metodológica utilizada no inventário e na avaliação quantitativa do patrimônio geológico do município. A seleção dos pontos do inventário foi realizada a partir de: (i) revisão bibliográfica; (ii) entrevistas com pesquisadores que desenvolveram pesquisas em geociências na região; (iii) análise de mapas geológicos, estruturais e imagens de satélites para definir as áreas potenciais; (iv) trabalhos de campo; e (v) seleção e descrição dos pontos. O inventário engloba oito geossítios, três sítios de geodiversidade de uso educativo e um de uso turístico, os quais são representativos da história geológica do município. A quantificação do patrimônio geológico foi realizada a partir de métodos existentes e a relevância dos sítios foi obtida com a finalidade de orientar futuras estratégias de geoconservação. De acordo com os resultados, somente o geossítio Captura Fluvial do Rio Guaratuba obteve a mesma posição no ranking nos dois métodos. Com base nos resultados, comparou-se o ranking obtido entre os métodos de modo a avaliar quais os parâmetros responsáveis pelos resultados distintos. Há no município treze Unidades de Conservação - UCs, que têm por prioridade a conservação da biodiversidade; atualmente não há nenhuma proposta de conservação da geodiversidade. Através dos resultados da avaliação do risco de degradação, concluiu-se que alguns sítios inseridos em UCs possuem risco de degradação moderado e necessitam de políticas públicas para a sua gestão.

Palavras-chave: Estratégias de geoconservação, geodiversidade, geossítios, litoral paulista, quantificação, sítios de geodiversidade.
\end{abstract}

Abstract - INVENTORY AND QUANTITATIVE ASSESSMENT OF THE GEOLOGICAL HERITAGE OF BERTIOGA (SP, BRAZIL). Bertioga is located on the coast of São Paulo State and is well known for outstanding geodiversity. This work aims to discuss the methodological approach used for the inventory and for the quantitative assessment of the Bertioga's geological heritage. The selection of the sites the inventory was carried out based on: (i) literature review; (ii) interviews with researchers who conduct geoscience research in the region; (iii) analysis of geological and structural maps and satellite images, for identified potential areas; (iv) field work; and (v) selection and description of the sites. The inventory include eight geosites, three geodiversity sites for educational use and one for touristic use, which are representative of the geological history of the municipality. The quantification of geological heritage was performed based on existing methods and the relevance of the sites was obtained and is intended to guide the choice of future geoconservation strategies. In accordance with the results, only the geosite River Capture of Guaratuba River obtained the same ranking in different methods. Based on the results, we compared the ranking obtained between the methods for available which parameters responsible for the different results. There are thirteen environmental protection areas within the municipality's limits, the priority is conservation of biodiversity, and actually, there is no proposal for the conservation of the geodiversity. Through the results of evaluation of degradation risk, we conclude although some sites are within the protected areas, some have moderate risk of degradation and need public policies for their management.

Keywords: geoconservation strategies, geodiversity, geosites, São Paulo coast, quantification, geodiversity site. 


\section{Introdução}

O patrimônio natural envolve os elementos da Biodiversidade e da Geodiversidade. No entanto, enquanto as ameaças à primeira têm sido objeto de diversas pesquisas realizadas nas últimas décadas e, por isso, diversas estratégias foram criadas para sua conservação, somente no final da década de 1990 é que as questões acerca da geodiversidade começaram a ser debatidas (Gray, 2004, 2005, 2013; Lima, 2008; Pereira et al., 2008). A geodiversidade consiste na "variedade natural (diversidade) de feições geológicas (rochas, minerais e fósseis), geomorfológicas (paisagem, topografia, processos físicos), solos e feições hidrogeológicas. Isso inclui as associações, estruturas, sistemas e contribuições para as paisagens" (Gray, 2013, p. 12). Os aspectos da geodiversidade são claramente observados nas paisagens e tem propiciado ambientes para o suporte da vida na Terra (Brilha, 2005; Pereira et al., 2008). Além disso, os registros geológicos e geomorfológicos permitem compreender a evolução da história da Terra. Durante muitas décadas, acreditou-se na falsa ideia de que a geodiversidade era resistente e duradoura, mas essa concepção mostrou-se equivocada, pois a geodiversidade apresenta extensões finitas e não renováveis, possuindo grande vulnerabilidade diante do uso desenfreado pela sociedade.

Neste contexto, a Geoconservação surge como um conjunto de estratégias e medidas para evitar que a geodiversidade seja destruída (Sharples, 2002; Gray, 2004, 2013; Brilha, 2005). Para Brilha $(2005,2016)$ as estratégias de geoconservação devem ser estabelecidas somente após um trabalho que indique o que realmente deve ser enquadrado como patrimônio geológico.

O patrimônio geológico consiste no conjunto de geossítios inventariados. Brilha (2005) definiu geossítio como a ocorrência de um ou mais elementos da geodiversidade, bem delimitado geograficamente, que possua valor do ponto de vista científico, educativo, cultural, turístico ou outro. Brilha (2016) conceituou as ocorrências da geodiversidade in situ como geossítios (valor científico) e como sítios de geodiversidade (outros valores). 0 mesmo autor (Brilha, 2005, 2016) elaborou um método sistemático para as tarefas no âmbito da geoconservação que tem início com os trabalhos de inventário, considerados primordiais para o sucesso das outras etapas.

o primeiro país do mundo a realizar o inventário do patrimônio geológico de forma sistemática foi a Grã-Bretanha na década de 1970, sendo a seleção dos geossítios baseada em sete frameworks. Atualmente o país possui mais de 3.000 geossítios (Ellis, 2008).

Em 1989, a International Union of Geological Sciences - IUGS criou a Lista Global de Sítios Geológicos - GILGES (Global Indicative List of Geological Sites) com objetivo de elaborar um inventário de sítios geológicos em nível mundial, posteriormente incorporados à lista do patrimônio mundial da UNESCO (United Nations Educational, Scientific and Cultural Organization). Inicialmente o método utilizado na seleção dos geossítios foi o ad hoc, que possui como desvantagem principal o fato de realizar uma avaliação isolada dos geossítios, sem considerar necessariamente o contexto geológico (Wimbledon et al., 1999). Em 1993, o Brasil, através do Departamento Nacional de Produção Mineral - DNPM, foi convidado a apoiar a GILGES e, em 1997, foi instituída a Comissão Brasileira de Sítios Geológicos e Paleobiológicos - SIGEP, para catalogar os sítios brasileiros indicados à GILGES. De acordo com Wimbledon et al. (1999), a seleção do patrimônio geológico pela SIGEP foi realizada a partir dos métodos ad hoc e de locais dotados de características superlativas. Por isso, não pode ser considerado como um inventário realizado com método sistemático.

Em substituição ao GILGES, a IUGS criou, em 1996, o Projeto Geosites, que tinha o objetivo de realizar o inventário dos geossítios mais importantes para a ciência geológica com relevância internacional. Este projeto foi realizado com método sistemático e envolveu colaboradores de diversos grupos internacionais que contribuíram para a realização dos inventários nacionais através da identificação e compilação de geossítios para o inventário internacional (Wimbledon, 1996; Wimbledon et al., 1999). Na Europa, o projeto Geosites foi realizado em cooperação com a Associação Europeia para a Conservação do Patrimônio Geológico (ProGeo) e escritórios nacionais da ProGeo (Wimbledon et al., 2000). Apesar do projeto ter sido finalizado em 2003 sem atingir os principais objetivos (IUGS, 2016), a ProGeo ainda promove os inventários de geossítios nos países europeus. Exemplos de inventários relacionados na Europa sob esta ótica são o da Espanha (García-Cortez \& Carcavilla Urquí, 2009) e o de Portugal (Brilha et al., 2010).

No Brasil, Pereira (2010) elaborou o inventário a partir de consultas aos geólogos da Companhia de Pesquisa de Recursos Minerais CPRM e conhecedores dos locais-chave para o entendimento da geologia e evolução da paisagem da Chapada Diamantina (BA). O inventário dos geossítios levou em conta os valores científico, 
didático e turístico, através de três frameworks definidos. 0 método utilizado no inventário se enquadra na seleção de locais dotados de características superlativas (Wimbledon et al., 1999) e o levantamento realizado se enquadra como um inventário de reconhecimento (Sharples, 2002). Além do inventário, o autor propôs um método de quantificação do patrimônio geológico que avalia 20 parâmetros.

Mais recentemente, o trabalho desenvolvido por Garcia et al. $(2015,2017)$ para o inventário do patrimônio geológico do Estado de São Paulo ao longo de três anos foi o primeiro a seguir um método sistemático, com a participação da comunidade geocientífica do Instituto de Geociências da Universidade de São Paulo, da Universidade do Minho, da CPRM e do Instituto Geológico do Estado de São Paulo.

0 presente trabalho tem por objetivo realizar o inventário de geossítios e sítios de geodiversidade no Município de Bertioga, SP. A seleção foi realizada pelo método de Brilha (2016) para áreas restritas e, em conjunto com outras pesquisas concluídas e em andamento, vai compor o inventário do litoral do Estado de São Paulo. A etapa de avaliação quantitativa foi realizada mesmo considerando-se o número reduzido de geossítios e sítios de geodiversidade, pois este faz parte de um projeto maior que tem por objetivo realizar estratégias de geoconservação ao longo de toda a região costeira do Estado de São Paulo (Garcia, 2012; Garcia et al., 2014). A quantificação foi realizada a partir dos métodos propostos por Pereira (2010) e Brilha (2016). 0 ranking obtido nesta etapa, em conjunto com a quantificação do risco de degradação - RD, pode ser utilizado para definir os sítios prioritários nas estratégias de geoconservação do município.

\section{2 Área, materiais e métodos}

\section{1 Área de estudo}

O Município de Bertioga localiza-se na extremidade nordeste da Região Metropolitana da Baixada Santista, no litoral central do Estado de São Paulo, a aproximadamente $110 \mathrm{~km}$ da capital paulista. Limita-se a sul com o Oceano Atlântico, a oeste com o Município de Santos, a sudoeste com Guarujá, a leste com São Sebastião e a norte com Mogi das Cruzes, Biritiba Mirim e Salesópolis. Abrange uma área de $491 \mathrm{~km}^{2}$, com população de aproximadamente 47.000 habitantes fixos, atingindo cerca de 85.000 habitantes durante a temporada de férias (IBGE, 2010).
O município está inserido no bioma da Mata Atlântica, sendo 91\% da área coberta por vegetação nativa, incluindo floresta de altitude, manguezais e restinga (Instituto Polis, 2013). De acordo com Ab'Saber $(2005,2006)$, os litorais são áreas complexas de inter-relação entre a terra, o mar e a dinâmica costeira. No litoral paulista esses fatores possibilitaram a formação de inúmeras praias ricas em vegetação de manguezal e de restinga. Aproximadamente $72 \%$ da área total do município insere-se em Unidades de Conservação - UCs (Instituto Polis, 2013): Parque Estadual da Serra do Mar - Núcleo Bertioga; Parque Estadual Restinga de Bertioga - PERB; Área de Proteção Ambiental Marinha do Litoral Centro; Área de Relevante Interesse Ecológico - ARIE Itaguaré; Reserva Particular do Patrimônio Natural - RPPN Ecofuturo; RPPN Hércules Florence I, II, III, IV, V, VI; RPPN Costa Blanca e Parque Municipal Ilha Rio da Praia (SMA/IF, 2006; SMA/FF, 2013). Para Conti \& Furlan (2005), os principais fatores que contribuem para o desenvolvimento da vegetação são a umidade e a temperatura, também são fatores essenciais o solo, o relevo e a altitude. A vegetação típica é da Floresta Tropical Pluvial com árvores altas e com grande diversidade de espécies. Quando essa mata atinge a Planície Costeira, encontra-se sobre cordões arenosos, sedimentos marinhos e sedimentos fluviais, que são mais pobres em nutrientes e tendem a gerar solos menos desenvolvidos, 0 que contribui para um número menor de espécies se comparada à Mata Atlântica. Na Planície Costeira ocorre a adaptação de novas espécies na denominada Mata de Restinga (Rossi, 1999).

Em termos hidrográficos, o município é drenado pelas bacias dos Rios Itapanhaú, Itaguaré e Guaratuba. De acordo com a classificação climática de Köppen a região possui um clima do tipo Af (clima úmido ou superúmido), com chuvas distribuídas em todos os meses do ano concentrando-se no verão (Santos, 1965; Mendonça \& Danni-Oliveira, 2007) e temperaturas médias anuais de 24,7 C (CEPAGRI, 2014). A massa de ar Tropical Atlântica de temperatura homogênea atua no município com certa instabilidade durante o verão quando entra em contato com a corrente marítima quente do Brasil (Santos, 1965).

Ab'Saber (2003) observou que a região da borda do Planalto Atlântico paulista é onde ocorrem as maiores médias de precipitação do país, com médias anuais de $4.500 \mathrm{~mm} /$ ano e fortes nevoeiros. Para Conti \& Furlan (2005) a maior média de precipitação no trecho paulista da Serra do Mar ocorre entre os Municípios de Bertioga e Taiaçupeba onde a isoieta é de aproximadamente 4.000 
$\mathrm{mm} / \mathrm{ano}$

\subsection{Contexto geológico e geomorfológico}

A região de Bertioga está inserida na Faixa Ribeira, que é um dos orógenos que compõem a Província Mantiqueira (Almeida et al., 1977, 1981), de idade neoproterozoica. Para Heilbron et al. (2004), sua origem é resultante da aglutinação de diversos paleocontinentes durante a formação do Gondwana Ocidental (Fig. 1). 0 Orógeno (Heilbron et al., 2004) ou Faixa Ribeira (Cordani et al., 1973) foi formado por conta do fechamento do Oceano Adamastor e a colisão entre os crátons São Francisco - Congo Ocidental, entre 650 - 510 Ma (Ciclo Tectônico Brasiliano Pan-Africano) e estende-se por mais de $1.000 \mathrm{~km}$ ao longo da costa atlântica brasileira. Para Heilbron et al. (2004), a maior parte da organização estrutural da região é resultante dos processos colisionais que causaram um trend estrutural NE-SW.

No município encontram-se as entidades tectono-estratigráficas do Terreno Serra do Mar e das Coberturas Sedimentares Cenozoicas. As unidades litoestratigráficas do Terreno Serra do Mar são representadas pela Unidade granito gnáissica migmatítica e pela Unidade ortognáissica do Complexo Costeiro, pelo Complexo granítico Pico do Papagaio e pelo Granito Taiaçupeba; as unidades litoestratigráficas das Coberturas Sedimentares Cenozoicas são representadas pelas Coberturas detríticas indiferenciadas e Coberturas litorâneas indiferenciadas (Perrotta et al., 2005). A Zona de Cisalhamento Bairro do Alto - ZCBA, de estrutura regional e orientação NE-SW, corta a região (Maffra, 2000).

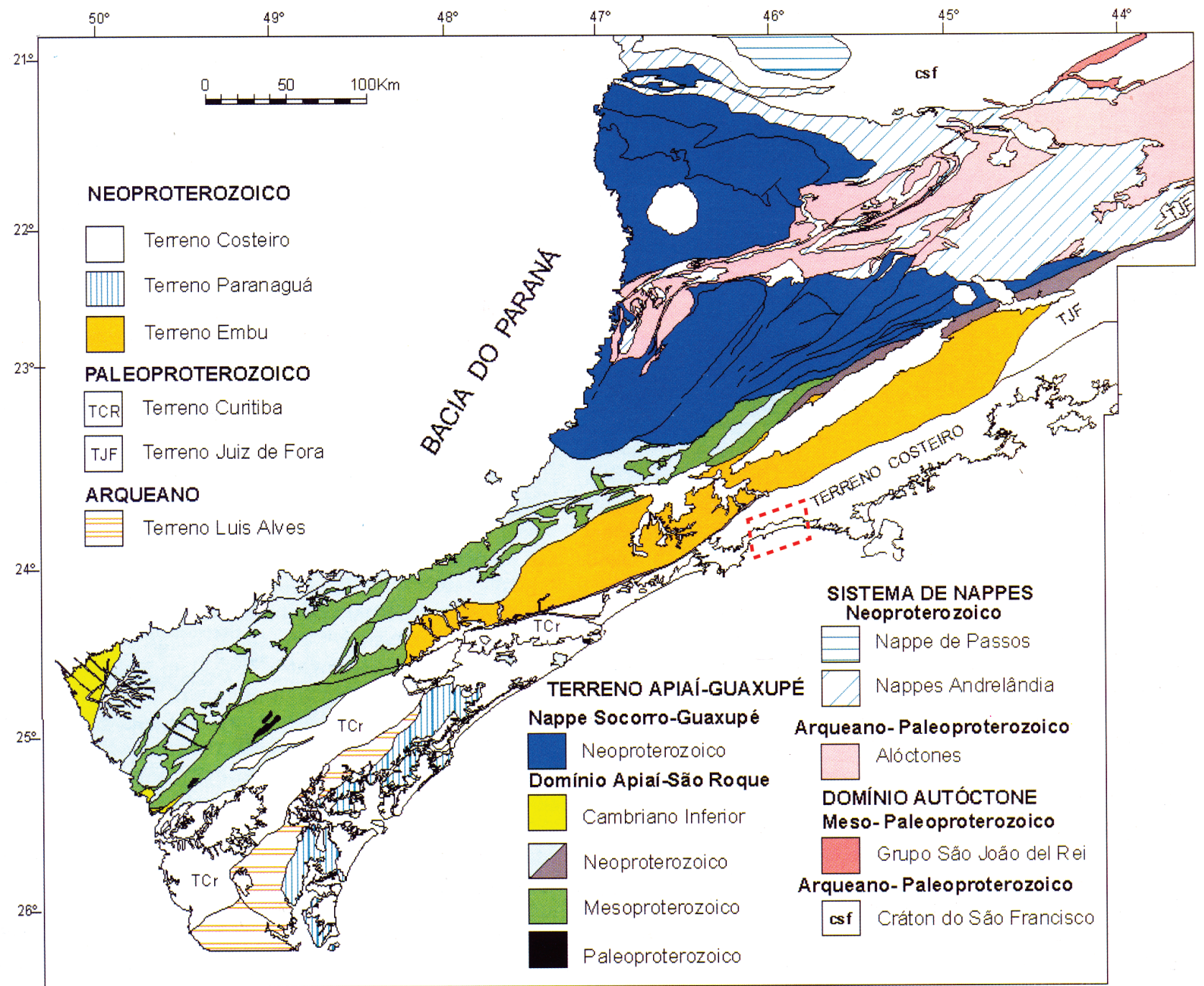

Figura 1. Mapa tectônico dos terrenos da Faixa Ribeira (Heilbron et al., 2004). O polígono em vermelho indica a área de estudo. Figure 1. Tectonic map of Ribeira Belt terrains (Heilbron et al., 2004). The red polygon indicates the studied area.

Geomorfologicamente, o município insere-se na província geológica-geomorfológica que Almeida (1964) definiu como Província Costeira, dividida em duas zonas: a Serraria Costeira e a Baixa- da Litorânea. A zona costeira tropical atlântica ou litoral sudeste (Ab'Saber, 2005) é o macro setor mais diversificado e acidentado de todo o país e se estende por cerca de $1.500 \mathrm{~km}$ desde o sul do Es- 
pírito Santo até o norte de Santa Catarina, região onde encontram-se reentrâncias nas quais se destacam as Planícies Costeiras.

Na zona de Serraria Costeira, as feições mais representativas correspondem à Serra do Mar, um grande alinhamento de escarpas costeiras de front abrupto e dissimétricos voltado para o oceano (Ab'Saber, 1950). Segundo Almeida \& Carneiro (1998), trata-se de um conjunto de escarpas com cerca de $1.000 \mathrm{~km}$ de extensão, com orientação ENE que acompanha a orientação do Escudo Atlântico e se estende do Rio de Janeiro ao norte de Santa Catarina, onde deixa de existir como unidade orográfica de borda escarpada de Planalto. Os autores apontam a feição como resultado do recuo erosivo de uma antiga escarpa de falha formada tectonicamente no Paleoceno, a dezenas de quilômetros da linha de costa atual. Os sedimentos provenientes foram levados para a borda da plataforma (formações Santos, Jureia e Itajaí-Açu) e para o interior (Formação Bauru). No Estado de São Paulo é caracterizada como típica borda de planalto com altitudes entre 800 a $1.200 \mathrm{~m}$.

A Baixada Litorânea é formada principalmente pelas Planícies Costeiras que, no Estado de São Paulo, destacam-se por suas áreas aumentarem regularmente de norte a sul (Suguio, 1976). Para Suguio \& Martin (1978), o litoral do estado pode ser dividido em duas partes distintas: a primeira engloba o litoral norte com o embasamento PréCambriano atingindo o mar em quase toda sua extensão; a segunda formada pelo litoral sul com grandes planícies flúviolagunares separadas entre si por pontões nos quais expõem-se rochas do embasamento Pré-Cambriano.

Em Bertioga, a Planície estende-se por aproximadamente $240 \mathrm{~km}^{2}$ de área, por uma distância de aproximadamente $45 \mathrm{~km}$ por 7 a $8 \mathrm{~km}$ de largura. Os rios Itapanhaú, Itaguaré e Guaratuba drenam as zonas mais baixas e, no passado, quando o nível do mar estava acima do atual, possivelmente formavam lagunas (Suguio \& Martin, 1978; Souza, 2015). Para Souza (2015) a evolução desta Planície foi influenciada por eventos tectônicos e por processos de flutuação do nível relativo do mar NRM durante o Quaternário. Essas características teriam propiciado a deposição de sedimentos em ambientes marinhos, estuarino lagunares, lacustres e fluviais, formados durante o Pleistoceno e o Holoceno, registrando sua evolução.

\subsection{Métodos}

2.3.1 Inventário de geossítios e sítios de geodiversdade
Brilha $(2005,2016)$ apresentou as seguintes etapas sequenciais para as propostas de geoconservação: inventário, quantificação, enquadramento legal, conservação, valorização/divulgação e monitoramento. A primeira etapa proposta por Brilha $(2005,2016)$ consiste no inventário e deve ser realizado de forma sistemática, pois é a base para todas as demais estratégias de geoconservação.

A história geológica do litoral paulista está relacionada essencialmente com eventos da amalgamação e fragmentação do Supercontinente Gondwana e vem sendo contada a partir de geossítios selecionados nos inventários de Ilhabela (Prochoroff, 2014), São Sebastião (Reverte, 2014; Reverte \& Garcia 2016), Ubatuba (Santos, 2014) e Caraguatatuba (Arruda et al., 2015). Trabalhos de inventário em Cananeia, Ilha Comprida, Iguape, Santos, São Vicente e Cubatão estão em andamento e pretendem compor um mosaico ao longo da região costeira do Estado de São Paulo.

0 método adotado na seleção das áreas com potenciais geossítios e sítios de geodiversidade foi apresentado por Mucivuna et al. (2015) e incluiu pontos descritos em publicações, locais indicados por pesquisadores que já trabalharam na região e áreas obtidas através da investigação em mapas e imagens de satélite.

A partir da seleção seguiu-se a análise das possibilidades de acesso, dificultado muitas vezes devido à densa cobertura vegetal, que se deu por trilhas ecoturísticas em UCs, costões rochosos e afloramentos de estrada. Os pontos selecionados foram então investigados em trabalhos de campo com o objetivo de definir sua inclusão ou não no inventário de Bertioga (Garcia et al., 2014).

\subsubsection{Avaliação quantitativa}

A quantificação tem por objetivo definir o ranking de relevância nas ações prioritárias nos geossítios e sítios de geodiversidade. Os métodos, geralmente, são baseados em diversos critérios que levam em conta seus atributos. Diversos autores têm desenvolvido métodos que buscam minimizar a subjetividade inerente a esse processo. A escolha do método adequado, de acordo com objetivo do trabalho, é de suma importância, pois aqueles que não se adequem à área de estudo podem gerar resultados inesperados.

Para o inventário do Município de Bertioga, foram adotados os métodos de Pereira (2010) e Brilha (2016). A escolha do primeiro ocorreu por ser brasileiro e já adaptado de diversos métodos europeus; o segundo foi escolhido por ser o mais 
recente e utilizado pela CPRM na plataforma GEOSSIT, que pretende englobar o patrimônio geológico nacional.

\section{Resultados}

\subsection{0 inventário}

O inventário do patrimônio geológico de Bertioga foi realizado a partir dos eventos-chave que representam cronologicamente a história geológica do município e engloba os seguintes geossítios: Registros Tectônicos da Cachoeira do Sertão, Milonitos da Praia de São Lourenço, Gnaisse do Canto do Itaguá, Mirante da Serra do Mar, Terraço Pleistoceno do Rio Itapanhaú, Terraço do Rio Guaratuba, Captura Fluvial do Rio Guaratuba e Terraços
Marinhos da Praia de Itaguaré. Os sítios de geodiversidade selecionados são: Granitos da Praia do Indaiá, Gnaisses da Praia de São Lourenço, Blocos Rolados do Rio Itatinga e Granitos da Cachoeira do Guaratuba (Fig. 2).

Os geossítios e sítios de geodiversidade foram classificados de acordo com a tipologia descrita por Fuertes-Gutiérrez \& Fernández-Martínez (2010). Além disso, a fragilidade e a vulnerabilidade destes locais foram mensuradas de acordo com as ameaças por fatores naturais e por atividades antrópicas, respectivamente. A unidade litoestratigráfica, de acordo com o mapeamento de Perrotta et al. (2005), correspondente a cada sítio, foi mencionada na descrição. Entretanto por tratar-se de um mapa na escala de 1:750.000, em alguns sítios o litotipo predominante não correspondia ao mesmo devido à sua escala de abrangência.

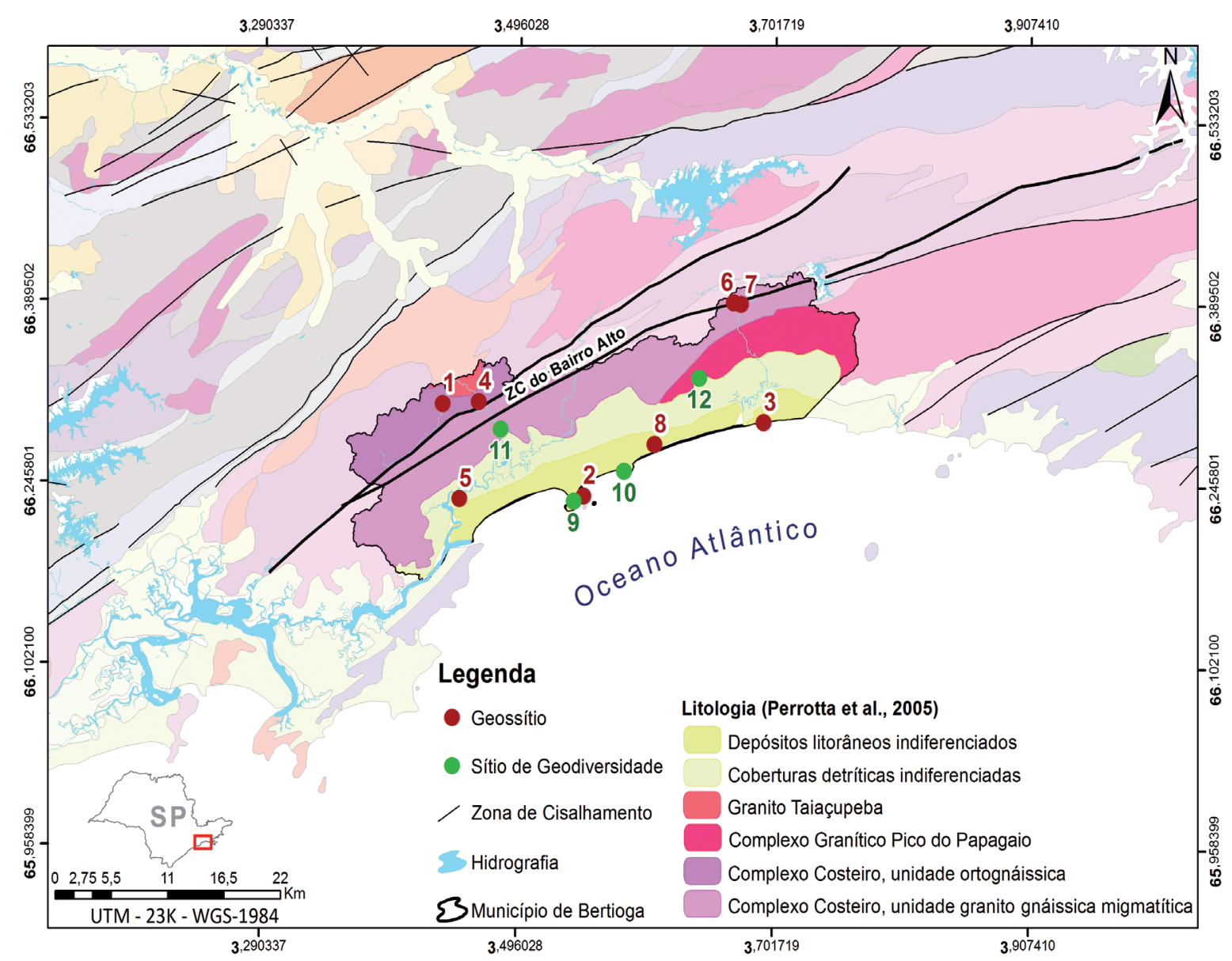

Figura 2. Mapa de localização dos geossítios e sítios de geodiversidade com base em Perrotta et al. (2005). Geossítios: 1) Registros Tectônicos da Cachoeira do Sertão; 2) Milonitos da Praia de São Lourenço; 3) Gnaisse do Canto do Itaguá; 4) Mirante da Serra do Mar; 5) Terraço Pleistoceno do Rio Itapanhaú; 6) Terraço do Rio Guaratuba; 7) Captura Fluvial do Rio Guaratuba; 8) Terraços Marinhos da Praia de Itaguaré. Sítios de Geodiversidade: 9) Granitos da Praia do Indaiá; 10) Gnaisses da Praia de São Lourenço; 11) Blocos Rolados do Rio Itatinga; 12) Granitos da Cachoeira do Guaratuba.

Figure 2. Location map of geosites and geodiversity sites based on Perrotta et al. (2005). Geosites: 1) Tectonic Records of Cachoeira do Sertão; 2) Mylonites of São Lourenço Beach; 3) Gneiss of Canto do Itaguá; 4) Viewpoint of Serra do Mar; 5) Pleistocene Terrace of Itapanhaú River; 6) Terrace of Guaratuba River; 7) River Capture of Guaratuba River; 8) Marine Terraces of Itaguaré Beach. Geodiversity sites: 9) Granites of Indaiá Beach; 10) Gneiss of São Lourenço Beach; 11) Rolled Stone Blocks of Itatinga River; 12) Granites of Cachoeira do Guaratuba. 


\subsubsection{Descrição dos geossítios}

\subsubsection{Geossítio Registros Tectônicos da Cachoeira do Sertão}

0 geossítio localiza-se no final da trilha da Cachoeira do Sertão, na margem direita do Rio Itatinga, dentro dos limites do Parque das Neblinas (Quadro 1).

Dois tipos litológicos principais ocorrem: granitoide fino foliado e gnaisse anfibolítico. 0 granitoide é intrusivo no gnaisse anfibolítico, fato evidenciado pelos enclaves máficos dentro do granitoide. Devido ao caráter menos resistente, os enclaves apresentam-se mais erodidos que o gnaisse e estão alongados na direção da foliação E-W (Fig. $3 \mathrm{~A})$. As porções máficas aparecem também como boudins que preservam a foliação anterior da rocha (Fig. 3B) e como dobras assimétricas (Fig. 3C).

Quadro 1. Descrição sucinta das características do Geossítio Registros Tectônicos da Cachoeira do Sertão. Chart 1. Brief description of the characteristics of the Geosite Tectonic Records of Cachoeira do Sertão.

\begin{tabular}{|l|l|}
\hline Localização Geográfica & Cachoeira do Sertão (0381907 / 7373303) \\
\hline Tipologia & Pontual \\
\hline Enquadramento Legal & Reserva Particular do Patrimônio Natural Ecofuturo: Parque das Neblinas \\
\hline Acesso & Seguir até o fim da trilha da Cachoeira do Sertão \\
\hline Dimensão aproximada & $600 \mathrm{~m}^{2}$ \\
\hline Caracterização sucinta & Afloramento de granitoide deformado intercalado a gnaisse anfibolítico \\
\hline Litotipo predominante & Rocha granitoide fina foliada \\
\hline Unidade (Perrotta et al., 2005) & Unidade ortognáissica \\
\hline
\end{tabular}

A foliação principal está orientada na direção ENE-WSW, com alto ângulo de mergulho e provavelmente associada à ZCBA que corta a área (Fig. 3E). A deformação paralelizou os litotipos (Fig. 3D).

O geossítio possui potencial educativo voltado para alunos do ensino superior e também interesse turístico, pois encontra-se numa trilha ecoturística em meio à Mata Atlântica no Parque das Neblinas, que já recebe visitantes; apresenta baixas vulnerabilidade e fragilidade.

\subsubsection{Geossítio Milonitos da Praia de São Lourenço}

O geossítio localiza-se no costão sul da Praia de São Lourenço, em área da União e não está protegido por nenhuma UC (Quadro 2).

$\mathrm{O}$ afloramento é composto por dois tipos litológicos principais: ortognaisse porfiroblástico e ortognaisse fino. 0 principal tipo litológico é o ortognaisse porfiroblástico com grau de deformação variável (Fig. 4A). 0 contato entre os tipos litológicos é por vezes bem marcado (Fig. 4B) e ocasionalmente de maneira difusa (Fig. 4C). Próximo ao contato, anfibólios bem desenvolvidos são observados no ortognaisse porfiroblástico (Fig. 4D). 0 ortognaisse fino encontra-se localmente dobrado (Fig. 4E). Intrusões de granito porfirítico ocorrem no contato entre os dois tipos litológicos e possui orientação distinta do restante do geossítio (Fig. $4 G)$.

0 conjunto rochoso encontra-se deformado (Fig. 4F) e as foliações do ortognaisse porfi- roblástico estão orientadas, em geral, na direção ENE-WSW, com alto ângulo de mergulho. A distribuição geométrica do traço da zona de cisalhamento associada sugere que se trate de um prolongamento da Zona de Cisalhamento Camburu (ZCC), que tem registros descritos em geossítios nos $\mathrm{Mu}-$ nicípios de Caraguatatuba (Arruda et al., 2015) e São Sebastião (Reverte, 2014; Reverte \& Garcia, 2016).

O geossítio possui potencial educativo voltado para alunos do ensino superior e turístico, pois se encontra numa praia muito visitada do município. Apesar de não estar inserido em UC, apresenta baixa fragilidade e moderada vulnerabilidade, pois o geossítio possui marcas de pichações que dificultam, localmente, o reconhecimento dos tipos litológicos.

\subsubsection{Geossítio Gnaisses do Canto do Itaguá}

O geossítio localiza-se no costão sul da Praia de Boraceia, dentro dos limites do PERB (Quadro $3)$.

Dois tipos litológicos principais ocorrem: ortognaisse tipo augen e granito fino leucocrático. 0 granito fino leucocrático apresenta provável proveniência intrusiva. Os dois litotipos encontram-se intercalados com baixo ângulo de mergulho (Fig. $5 \mathrm{~A}$ ) e bandamento orientado segundo a foliação geral (Fig. 5B). 0 ortognaisse tipo augen faz contato com biotita gnaisse fino porfiroblástico (contato não visível) ao longo de uma foliação de alto ângulo e direção ENE-WSW (Fig. 5C). Intrusões de 
veios pegmatíticos paralelizados à foliação de alto

uma zona de cisalhamento.

ângulo (Fig. 5D) estão provavelmente associados a
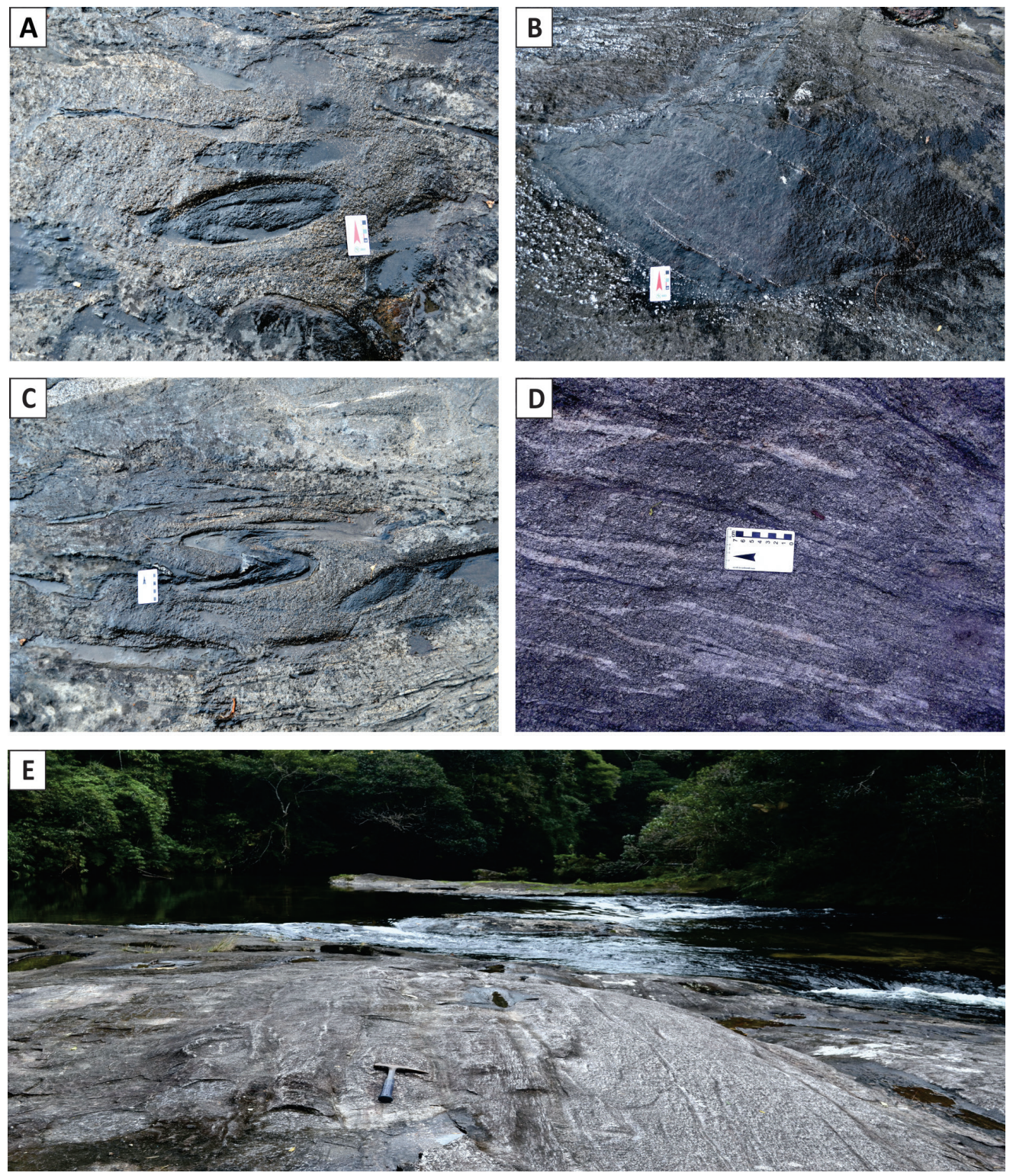

Figura 3. Geossítio Registros Tectônicos da Cachoeira do Sertão. A) Granitoide intrusivo no gnaisse anfibolítico, com enclaves máficos alongados na direção da foliação E-W; B) Boudin que preserva a foliação anterior; C) Porções máficas com dobras apertadas e isoclinais; D) Granitoide e gnaisse paralelizados com foliação de alto ângulo; E) Foliação de alto ângulo presente no geossítio, provavelmente associada à Zona de Cisalhamento Bairro do Alto (ZCBA).

Figure 3. Geosite Tectonic Records of Cachoeira do Sertão. A) Intrusive granitoid in amphibolitic gneiss, with mafic enclaves elongated in the E-W foliation direction; B) Boudin that preserves the previous foliation; $C$ ) Mafic portions with tight and isoclinal folds; D) Parallelized granitoid and gneiss with high angle foliations; E) High angle foliations present in geosite probably associated with Bairro do Alto Shear Zone (BASZ).

Quadro 2. Descrição sucinta das características do Geossítio Milonitos da Praia de São Lourenço. Chart 2. Brief description of the characteristics of the Geosite Mylonites of São Lourenço Beach.

\begin{tabular}{|l|l|}
\hline Localização Geográfica & Costão sul da Praia de São Lourenço (0394542 / 7365246) \\
\hline Tipologia & Pontual \\
\hline Enquadramento Legal & Patrimônio da União \\
\hline Acesso & $\begin{array}{l}\text { Seguir pela Rod. Manoel Hypólito do Rego (SP-055) até a entrada para a Praia de } \\
\text { São Lourenço }\end{array}$ \\
\hline Dimensão aproximada & $28.000 \mathrm{~m}^{2}$ \\
\hline Caracterização sucinta & Afloramento de ortognaisse milonítico \\
\hline Litotipo predominante & Ortognaisse porfiroblástico \\
\hline Unidade (Perrotta et al., 2005) & Depósitos litorâneos indiferenciados \\
\hline
\end{tabular}



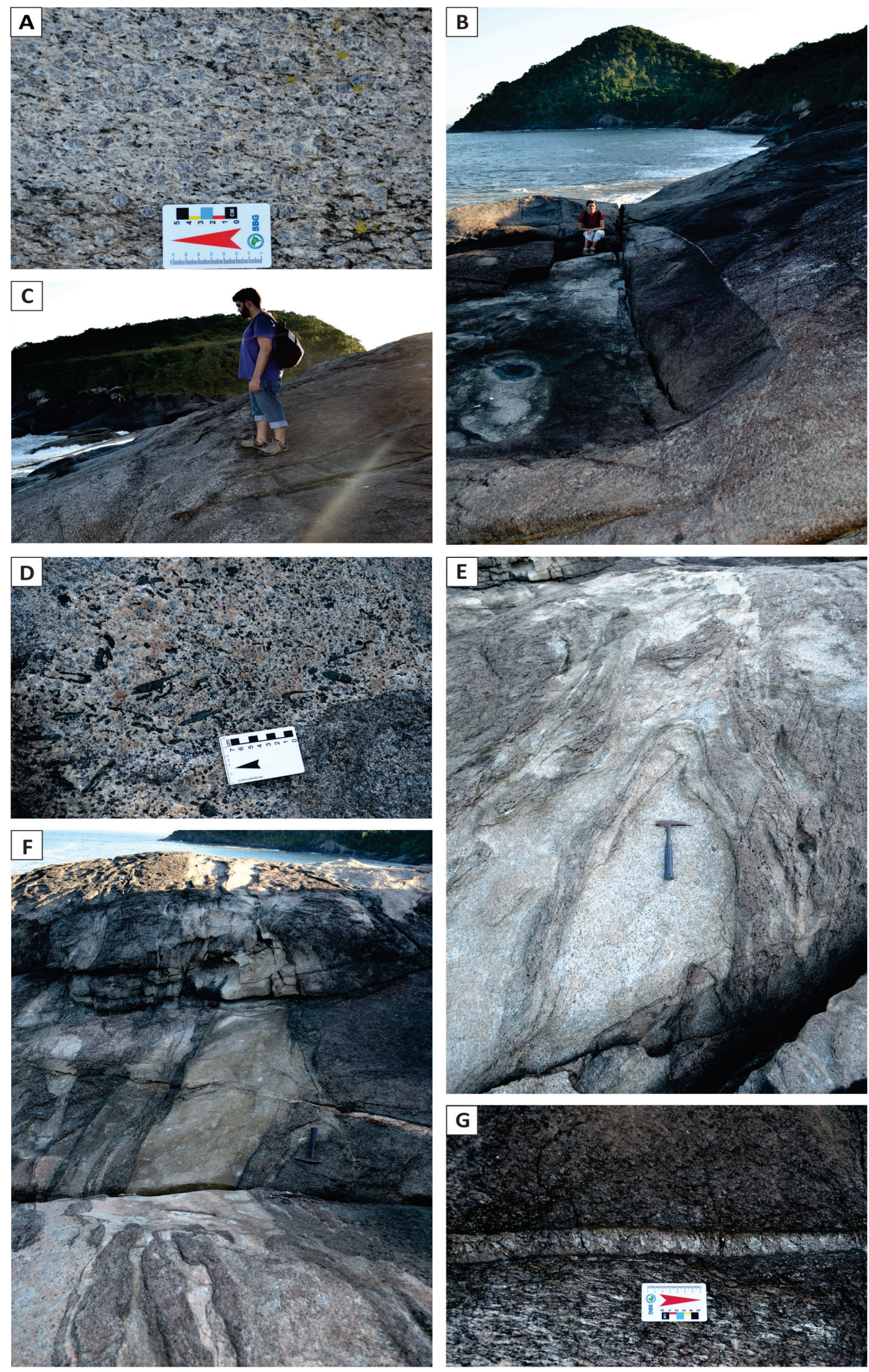

Figura 4. Geossítio Milonitos da Praia de São Lourenço. A) Detalhe do ortognaisse porfiroblástico; B) Contato abrupto entre o ortognaisse fino (esquerda e ao fundo) e o ortognaisse porfiroblástico (direita e a frente); C) Contato difuso entre o ortognaisse fino (direita) e o ortognaisse porfiroblástico (esquerda); D) Detalhe de anfibólios concentrados no ortognaisse porfiroblástico próximo ao contato; E) Ortognaisse fino dobrado; F) Deformação dos dois tipos litológicos; G) Intrusão de granito porfirítico com orientação distinta do ortognaisse fino (superior) e o ortognaisse porfiroblástico (inferior), detalhe para os cristais deformados.

Figure 4. Geosite Mylonites of São Lourenço Beach. A) Details of porphyroblastic orthogneiss; B) Abrupt contact between the fine orthogneiss (left and background) and the porphyroblastic orthogneiss (right and foreground); C) Diffuse contact between the fine orthogneiss (right) and the porphyroblastic orthogneiss (left); D) Details of amphiboles concentrated in porphyroblastic orthogneiss near the contact; E) Folded fine orthogneiss; F) Deformation in two lithologic types; G) Intrusion in porphyritic granite with different orientation of fine orthogneiss (top) and the porphyroblastic orthogneiss (bottom), details of the deformed crystals. 
A foliação geral é plano axial a dobras intrafoliais apertadas (Fig. 5E). A foliação de baixo ângulo é cortada por planos de alto ângulo resultantes de um cisalhamento destral (Fig. 5F).

Quadro 3. Descrição sucinta das características do Geossítio Gnaisses do Canto do Itaguá.

Chart 3. Brief description of the characteristics of the Geosite Gneiss of Canto do Itaguá.

\begin{tabular}{|l|l|}
\hline Localização Geográfica & Costão sul da Praia de Boraceia (0410638 / 7371820) \\
\hline Tipologia & Pontual \\
\hline Enquadramento Legal & Parque Estadual Restinga de Bertioga \\
\hline Acesso & $\begin{array}{l}\text { Seguir pela Rod. Manoel Hypólito do Rego (SP-055) até a entrada para o Cantão do } \\
\text { Itaguá, seguindo até chegar à Praia de Boraceia }\end{array}$ \\
\hline Dimensão aproximada & $11.000 \mathrm{~m}^{2}$ \\
\hline Caracterização sucinta & Afloramento de ortognaisse deformado intercalado com granito fino leucocrático \\
\hline Litotipo predominante & Ortognaisse porfiroblástico \\
\hline Unidade (Perrotta et al., 2005) & Depósitos litorâneos indiferenciados \\
\hline
\end{tabular}

Um dique pegmatítico corta o conjunto rochoso e é utilizado pelas pessoas que vão ao costão como uma "escada natural" (Fig. 5G). Um dique de diabásio com cerca de $30 \mathrm{~cm}$ de espessura corta o costão verticalmente, sendo sua porção central caracterizada por uma série de fraturas, possivelmente associadas ao resfriamento, ao longo das quais houve um deslocamento de cerca de $20 \mathrm{~cm}$ (Fig. 5H).

0 geossítio possui potencial educativo voltado para alunos do ensino superior e turístico, pois se encontra numa praia muito visitada do município; apresenta baixa fragilidade e moderada vulnerabilidade pois, localmente, possui marcas de pichações prejudicando sua integridade.

\subsubsection{Geossítio Mirante da Serra do Mar}

0 geossítio consiste em um mirante a $700 \mathrm{~m}$ de altitude, no final da trilha do Mirante, que se inicia no Parque das Neblinas e passa pela área da Companhia de Docas do Estado de São Paulo, próximo à barragem da Usina de Itatinga (Quadro 4).

A partir do mirante é possível observar importantes feições geomorfológicas como a Serra do Mar (Fig. 6A) e a Planície Costeira (Fig. 6B e C), resultantes dos eventos de fragmentação do Supercontinente Gondwana e posterior abertura do Atlântico Sul. Do geossítio observa-se o Canto do Indaiá, que foi unido ao continente através da Planície Costeira durante a última fase regressiva (Suguio \& Martin, 1978). Aproximadamente $80 \mathrm{~m}$ antes do mirante observa-se o Rio Itatinga represado e sua queda sobre um grande afloramento gnáissico (Fig. 6D).

Ao longo da trilha que leva ao mirante ob- servam-se afloramentos de gnaisses miloníticos orientados na direção E-W com alto ângulo de mergulho, associados à ZCBA.

O geossítio possui potencial educativo para o público geral, pois sua vista panorâmica proporciona a inter-relação entre os aspectos da formação da Serra do Mar e da Planície Costeira, além dos afloramentos de gnaisse milonítico que agregam valor ao geossítio. Também possui valor turístico e já conta com ampla visitação. Apresenta baixas vulnerabilidade e fragilidade, pois envolve grandes feições geomorfológicas e insere-se num parque que restringe o número de visitantes.

\subsubsection{Geossítio Terraço Pleistoceno do Rio Itapa- nhaú}

O geossítio localiza-se na margem esquerda do Rio Itapanhaú, em área pertencente à União e não se encontra protegido por nenhuma UC (Quadro 5 e fig. $7 \mathrm{~A}$ ).

O terraço é formado por depósitos de antigos sedimentos marinhos sobrepostos a de paleoambientes fluviais (Fig. 7B), sendo exposto devido à erosão flúviomarinha no canal do Rio Itapanhaú. A falésia de aproximadamente $7 \mathrm{~m}$ de altura subdivide-se em quatro seções de acordo com a origem dos sedimentos: sedimentos finos/orgânicos (0$117 \mathrm{~cm}$ ) - (Fig. 7C), sedimentos marinhos pedogeneizados (117-259 cm) - (Fig. 7D), sedimentos de transição entre ambiente fluvial e marinho (259$295 \mathrm{~cm}$ ) e sedimentos fluviais $(295-695 \mathrm{~cm})$ - (Fig. 7E) (Martins, 2009). A transição entre os ambientes é marcada pela mudança da granulometria e pelo grau de seleção e correlaciona-se com a energia dos agentes de transporte (Martins, 2009). 

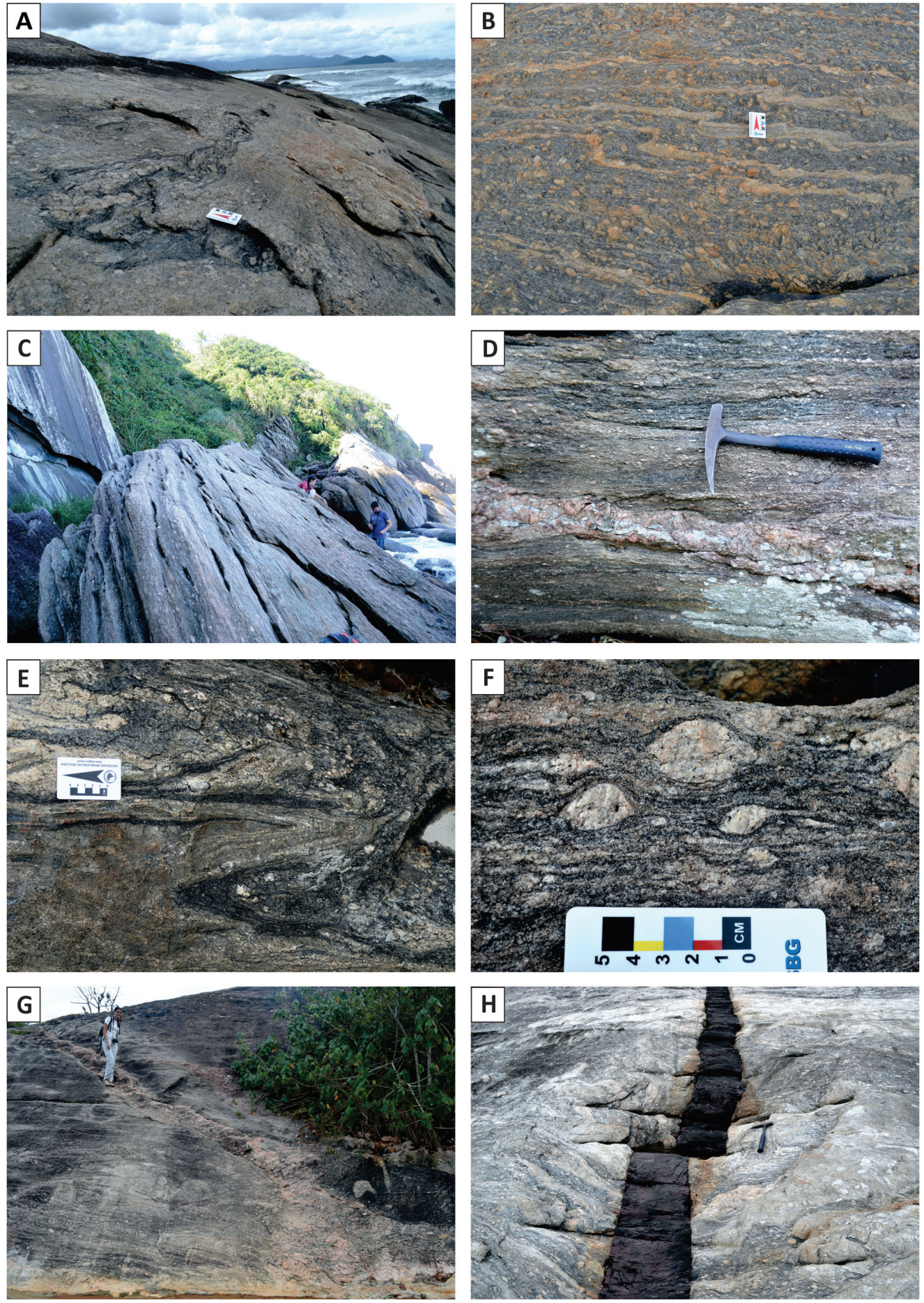

Figura 5. Geossítio Gnaisses do Canto do Itaguá. A) Intercalação entre o ortognaisse e o granito fino com baixo ângulo de mergulho; B) Bandamento dado pela paralelização entre o ortognaisse e o granito fino; C) Contato não observável entre o ortognaisse tipo augen (primeiro plano) e o biotita gnaisse porfiroblástico; D) Intrusão pegmatítica paralela à foliação de alto ângulo no ortognaisse tipo augen provavelmente associada a uma zona de cisalhamento; E) Dobras intrafoliais com planos axiais paralelos à foliação; F) Detalhe dos porfiroblastos de feldspatos assimétricos que indicam cisalhamento destral; G) Dique pegmatítico cortando o conjunto rochoso com baixo ângulo; H) Dique máfico deslocado pelo sistema de fraturas e contato entre o ortognaisse tipo augen e o granito fino leucocrático.

Figure 5. Geosite Gneiss of Canto do Itaguá. A) Intercalation between the orthogneiss and the fine granite with low dip angle; B) Banding given by parallelization between the orthogneiss and the fine granite; $C$ ) Unobservable contact between the type augen orthogneiss (foreground) and the porphyroblastic biotite gneiss; D) Pegmatitic intrusion parallel to the high-angle foliation in augen orthogneiss probably associated with a shear zone; E) Intrafolial folds with axial planes parallel to the foliation; F) Details of asymmetric feldspar porphyroblasts that indicate dextral shear; G) Pegmatitic dikes cutting the outcrop at a low angle; H) Mafic dike displaced by the fractures system and contact between the augen orthogneiss and the fine leucocratic granite. 
Quadro 4. Descrição sucinta das características do Geossítio Mirante da Serra do Mar. Chart 4. Brief description of the characteristics of the Geosite Viewpoint of Serra do Mar.

\begin{tabular}{|l|l|}
\hline Localização Geográfica & Final da trilha do Mirante (0385138 / 7373498) \\
\hline Tipologia & Mirante \\
\hline Enquadramento Legal & Parque Estadual da Serra do Mar \\
\hline Acesso & Seguir até o final da trilha do Mirante \\
\hline Dimensão aproximada & $1.500 \mathrm{~m}^{2}$ (ponto de observação) \\
\hline Caracterização sucinta & Observação de feições geomorfológicas da Serra do Mar e da Planície Costeira \\
\hline Litotipo predominante & --- \\
\hline Unidade (Perrotta et al., 2005) & Unidade ortognáissica \\
\hline
\end{tabular}
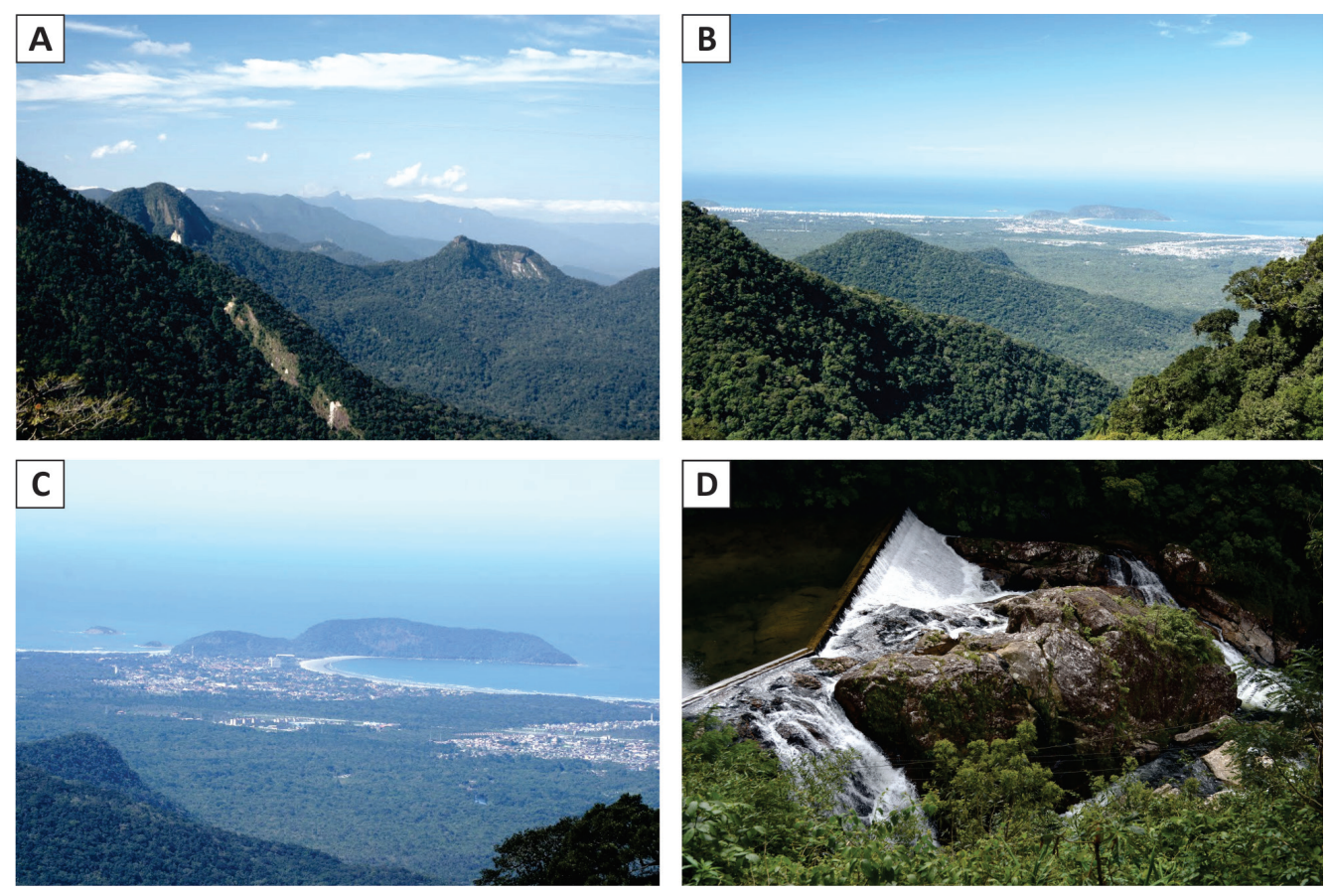

Figura 6. Geossítio Mirante da Serra do Mar. A) Vista do geossítio das escarpas da Serra do Mar; B) Vista do geossítio para a Praia da Enseada, Canto do Indaiá e Praia de São Lourenço; C) Vista do geossítio para o Canto do Indaiá (Geossítio Milonitos da Praia de São Lourenço) e Ilha Monte Pascoal, destaque para a Planície de Bertioga; D) Rio Itatinga represado a poucos metros do mirante. (Imagens A, B e C: autoria de André Pimentel).

Figure 6. Geosite Viewpoint of Serra do Mar. A) View of the Serra do Mar cliffs; B) View of Enseada Beach, Canto do Indaiá and São Lourenço Beach; C) View of Canto do Indaiá (Geosite Mylonites of São Lourenço Beach) and Monte Pascoal Island, highlighting the Bertioga Plain; D) Dammed Itatinga River a few meters from the viewpoint. (Images A, B and C: authorship of André Pimentel).

Quadro 5. Descrição sucinta das características do Geossítio Terraço Pleistoceno do Rio Itapanhaú. Chart 5. Brief description of the characteristics of the Geosite Pleistocene Terrace of Itapanhaú River.

\begin{tabular}{|l|l|}
\hline Localização Geográfica & Margem esquerda do Rio Itapanhaú (0383439 / 7364935) \\
\hline Tipologia & Pontual \\
\hline Enquadramento Legal & Patrimônio da União \\
\hline Acesso & $\begin{array}{l}\text { A partir do bairro Vicente de Carvalho seguir pela trilha a direita antes de chegar à } \\
\text { marina Poço do Robalo }\end{array}$ \\
\hline Dimensão aproximada & $300 \mathrm{~m}^{2}$ \\
\hline Caracterização sucinta & Terraço marinho no topo e terraço fluvial na base \\
\hline Litotipo predominante & Depósito sedimentar arenoso \\
\hline Unidade (Perrotta et al., 2005) & Coberturas detríticas indiferenciadas \\
\hline
\end{tabular}

O geossítio constitui-se como uma associação complexa de remanescentes de terraço marinho alto com terraço fluvial, ambos do Pleistoceno (Souza, 2015), e representativos de uma fase transgressiva do NRM (Martin \& Suguio, 1976).
Três pontos do terraço foram datados pelo método de Luminescência Opticamente Estimulada - LOE e apresentaram as seguintes idades: $162.000 \pm$ 27.500 anos antes do presente (AP) para a camada fluvial, $119.600 \pm 17.700$ anos AP para os sedi- 
mentos marinhos e $28.800 \pm 6.200$ anos AP para as areias álbicas do horizonte E do espodossolo (Martins, 2009). Esses resultados sugerem correlações entre esses depósitos fluviais e as formações Cananeia e Morro de Icapara (Souza, 2015).

0 geossítio possui potencial educativo, voltado para alunos de ensino médio e ensino superior, pois exemplifica os processos de variação do NRM e processos erosivos. Atualmente não possui valor turístico. Apresenta alta fragilidade por conta da erosão flúviomarinha decorrente das variações da maré e baixa vulnerabilidade.

\subsubsection{Geossítio Terraço do Rio Guaratuba}

O geossítio localiza-se no lado esquerdo da estrada de acesso à Estação Elevatória do Rio Guaratuba - EERG a cerca de $600 \mathrm{~m}$ antes do fim da estrada, dentro dos limites da Estação Ecológica Boraceia - EBB (Quadro 6).

Corresponde a um perfil de Espodossolo hidromórfico com cascalho (Oliveira, 2003) e apresenta uma linha de seixos arredondados de tamanho centimétrico, depositados em contato discordante com o gnaisse fino milonítico do embasamento (Fig. 8A e B).
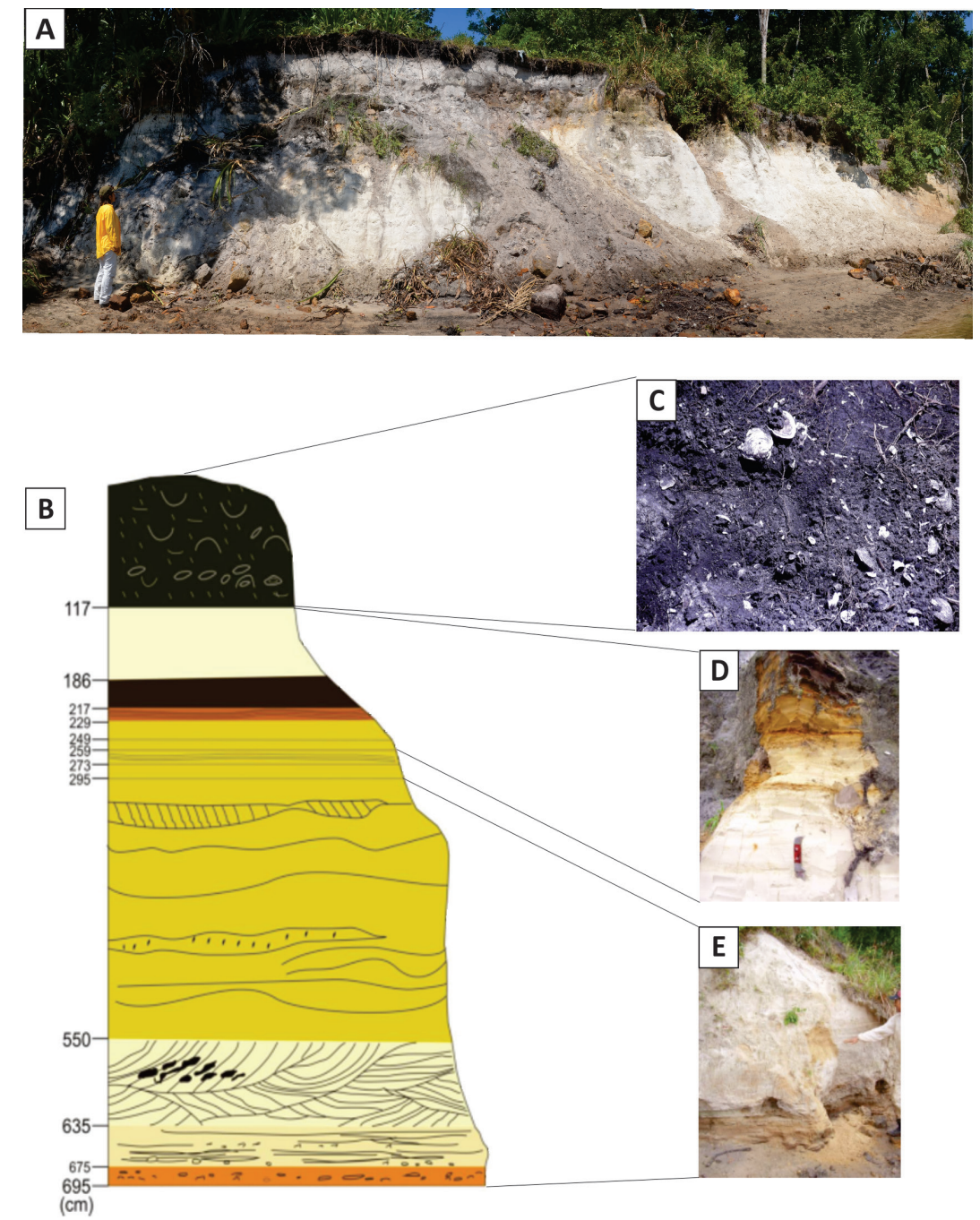

Figura 7. Geossítio Terraço Pleistoceno do Rio Itapanhaú. A) Vista geral do geossítio; B) Perfil esquemático dos horizontes e tipos de sedimentos que compõem o geossítio; C) Detalhe das conchas localizadas no topo do depósito marinho, na camada de sedimentos orgânicos; D) Detalhe dos sedimentos marinhos pedogeneizados; E) Detalhe dos sedimentos fluviais do Pleistoceno. Imagens B, D e E retiradas de Martins (2009).

Figure 7. Geosite Pleistocene Terrace of Itapanhaú River. A) General view of geosite; B) Schematic profile of horizons and sediment types that compose the geosite; $C$ ) Details of shells located on the top of marine deposits, in the organic sediments; D) Details of marine sediments after pedogenesis; E) Details of Pleistocene fluvial sediments. Images B, D and E extracted from Martins (2009).

Segundo Rossi (1999) e Rossi \& Queiroz Neto (2002), o horizonte superficial A é comum a todo perfil, abaixo observa-se a linha de seixos de deposição fluvial que representa um terraço suspenso gerado por processo de deposição de baixa seleção e na base a rocha alterada tem estrutura preser- vada.

A cascalheira estudada por Rossi (1999) corresponde ao testemunho de um antigo terraço fluvial do Rio Guaratuba (Fig. 8C) num trajeto anterior à sua captura quando este ainda se dirigia para o Rio Claro (Oliveira, 2003; Neves, 2012). 
Feições de erosão diferencial em pedestal (Fig. 8D) também são observadas (Rocha, 2004).

0 geossítio possui potencial educativo voltado para alunos do ensino fundamental II e médio, como exemplo do registro de antigo terraço fluvial através da linha de seixos. No ensino superior, pode ser utilizado com fins didáticos como exemplo de erosão hídrica. Atualmente o geossítio não possui valor turístico e apresenta baixas fragilidade e vulnerabilidade.

\subsubsection{Geossítio Captura Fluvial do Rio Guaratuba}

O geossítio localiza-se no final da estrada de acesso à EERG, dentro dos limites da EBB (Quadro
7).

Compreende duas subáreas, que têm em comum o fato de consistirem em feições associadas à ZCBA: (i) um afloramento, na margem direita do Rio Guaratuba, de ortognaisse milonítico associado a porções máficas com aspecto bandado. Injeções de granito róseo ocorrem no ortognaisse porfiroblástico, ambos deformados e associados à ZCBA (Fig. 9A e B); (ii) o cotovelo de uma captura fluvial desenvolvida a partir da erosão regressiva da escarpa da Serra do Mar, devido à mudança brusca de direção próximo à sua borda (Oliveira, 2003, 2010; Oliveira \& Queiroz Neto, 2007), (Fig. 9C, D e E).

Quadro 6. Descrição sucinta das características do Geossítio Terraço do Rio Guaratuba Chart 6. Brief description of the characteristics of the Geosite Terrace of Guaratuba River.

\begin{tabular}{|l|l|}
\hline Localização Geográfica & Estação Biológica Boraceia (0407890 / 7382342) \\
\hline Tipologia & Pontual \\
\hline Enquadramento Legal & Estação Ecológica Boraceia inserida no Parque Estadual da Serra do Mar \\
\hline Acesso & $\begin{array}{l}\text { Seguir pela estrada da Sabesp dentro da Estação Ecológica Boraceia até chegar } \\
\text { à Estação Elevatória do Rio Guaratuba }\end{array}$ \\
\hline Dimensão aproximada & $500 \mathrm{~m}^{2}$ \\
\hline Caracterização sucinta & Espodossolo ferrocárbico hidromórfico típico álico \\
\hline Litotipo predominante & Gnaisse fino milonítico \\
\hline Unidade (Perrotta et al., 2005) & Unidade granito gnáissica migmatítica \\
\hline
\end{tabular}
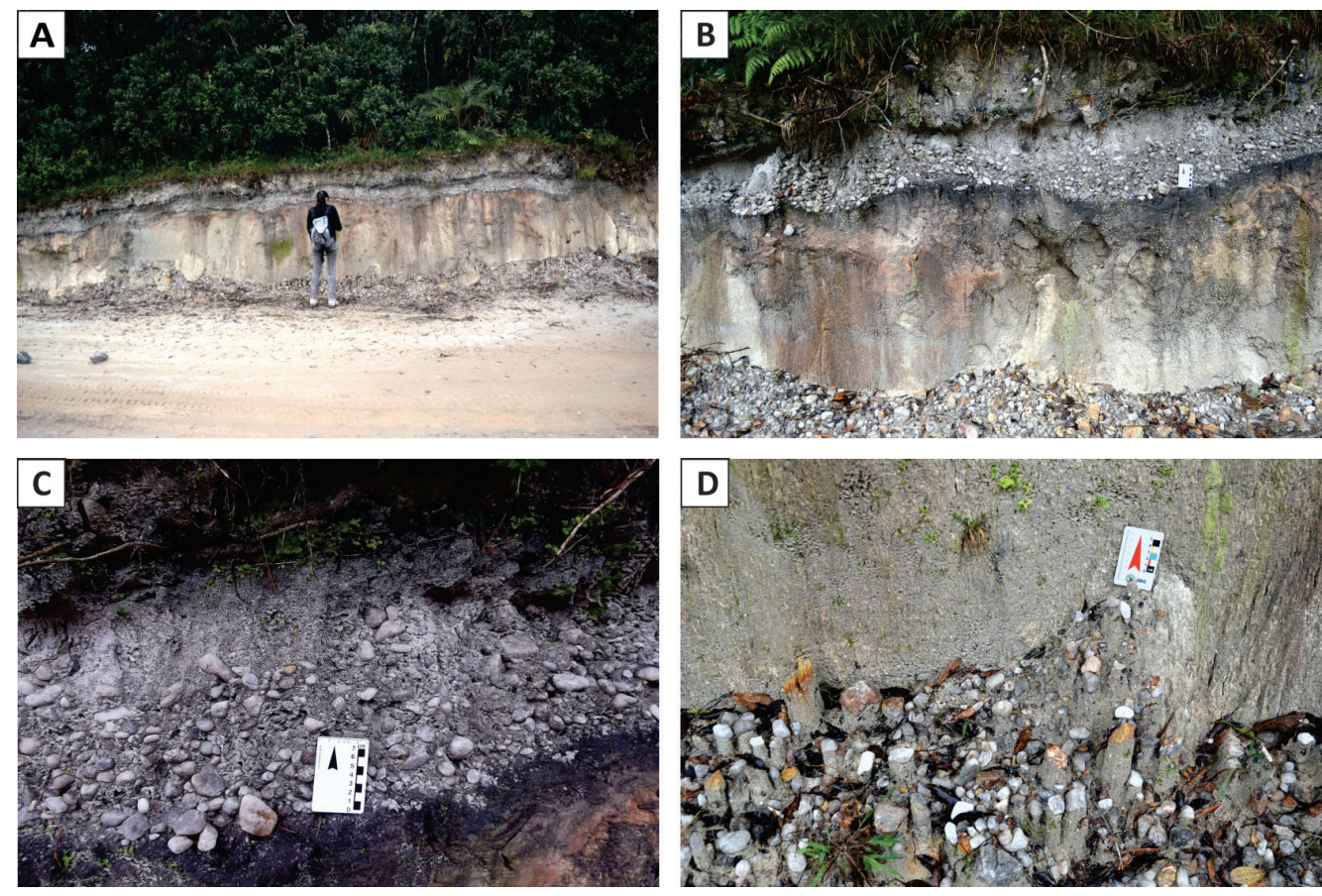

Figura 8. Geossítio Terraço do Rio Guaratuba. A) Vista geral do geossítio; B) Linha de seixos em contato discordante com o gnaisse milonítico do embasamento; C) Linha de seixos arredondados com tamanho centimétrico; D) Detalhe de erosão hídrica em pedestal.

Figure 8. Geosite Terrace of Guaratuba River. A) General view of geosite; B) Stone line in discordant contact with the mylonitic gneiss of basement; $C$ ) Lines of rounded stone centimeters in size; D)Details of water erosion on pedestal. 
Quadro 7. Descrição sucinta das características do Geossítio Captura Fluvial do Rio Guaratuba. Chart 7. Brief description of the characteristics of the Geosite River Capture of Guaratuba River.

\begin{tabular}{|l|l|}
\hline Localização Geográfica & Estação Biológica Boraceia $(0408542 / 7382218)$ e $(0408598 / 7382172)$ \\
\hline Tipologia & Área complexa \\
\hline Enquadramento Legal & Estação Ecológica Boraceia inserida no Parque Estadual da Serra do Mar \\
\hline Acesso & $\begin{array}{l}\text { Seguir pela estrada da Sabesp dentro da Estação Ecológica Boraceia até chegar à } \\
\text { Estação Elevatória do Rio Guaratuba }\end{array}$ \\
\hline Dimensão aproximada & $20.000 \mathrm{~m}^{2}$ \\
\hline Caracterização sucinta & $\begin{array}{l}\text { Geossítio de área complexa com a presença de um afloramento de ortognaisse milo- } \\
\text { nítico e da captura fluvial do Rio Guaratuba. }\end{array}$ \\
\hline Litotipo predominante & Ortognaisse milonítico \\
\hline Unidade (Perrotta et al., 2005) & Unidade granito gnáissica migmatítica \\
\hline
\end{tabular}

A montante, o Rio Guaratuba acompanha a ZCBA; próximo ao cotovelo observa-se o ortognaisse milonítico associado a esta. Neste trecho, o rio corre perpendicular às estruturas do ortognaisse milonítico, as foliações estão orientadas, em geral, na direção ENE-WSW com altos a médios ângulos de mergulho (Fig. 9F).

A captura fluvial (Christofoletti, 1975) do Rio Guaratuba foi interpretada como uma resposta à última fase da reativação tectônica do Rift Continental do Sudeste do Brasil no final do Pleistoceno e início do Holoceno (Riccomini et al., 2004). Datações pelo método LOE em dois perfis de solo localizados próximo à captura fluvial determinou a idade máxima de $29.000 \pm 5.000$ anos AP e mínima de $10.000 \pm 1.000$ anos AP (Neves, 2012); a idade máxima corresponde ao Pleistoceno e corrobora com o período proposto por Riccomini et al. (2004).

O Rio Guaratuba no seu primeiro trecho possui direção geral NE-SW (Fig. 9C) e, após o cotovelo da captura fluvial (Fig. 9D), muda bruscamente sua direção para N-S (Oliveira, 2003, 2010; Oliveira \& Queiroz Neto, 2007). O curso pretérito do Rio Guaratuba dirigia-se para a Bacia do Rio Claro, afluente do Rio Tietê, mas atualmente deságua no Oceano Atlântico. Esse fato foi comprovado por Ribeiro et al. (2006) através da presença de espécies de peixes encontradas no Alto Rio Guaratuba e na Bacia do Alto Tietê e não encontradas no Baixo Rio Guaratuba.

O potencial educativo do geossítio é voltado para alunos de ensino superior, pois exemplifica os registros tectônicos decorrentes da amalgamação do Supercontinente Gondwana através da ZCBA e do cotovelo de captura fluvial formada pela erosão regressiva da Serra do Mar. Apresenta baixas fragilidade e vulnerabilidade.

\subsubsection{Geossítio Terraços Marinhos da Praia de Ita- guaré}

0 geossítio localiza-se na Praia de Itaguaré, próximo à foz do rio homônimo que possui padrão meandrante e insere-se dentro dos limites do PERB (Quadro 8).

Compreende três subáreas, que têm em comum o fato de constituírem feições associadas à dinâmica costeira decorrentes das variações do NRM: (i) um afloramento, na margem direita do Rio Itaguaré, de gnaisse milonítico com veios de quartzo e alto ângulo de mergulho associados a uma zona cisalhamento (Fig. 10A); (ii) uma falésia em terraço marinho de idade pleistocena com aproximadamente $5 \mathrm{~m}$ de altura, próximo a foz do Rio Itaguaré, que apresenta da base para o topo: areia com cimento ferruginoso (cerca de $1 \mathrm{~m}$ de espessura), areia fina acinzentada estratificada (cerca de $1 \mathrm{~m}$ de espessura), areia fina branca (cerca de 2 m de espessura) e Espodossolo com horizonte ortstein e vegetação de alta restinga (Fig. 10B). A formação da falésia é atribuída à erosão flúviomarinha ativa na Foz do Rio Itaguaré, relacionada às variações do NRM durante o Quaternário (Fig. 10C); (iii) um terraço marinho de idade holocena localizado próximo a canais de drenagens que deságuam no mar (Martins, 2009).

No passado, a subárea (i) pode ter funcionado como uma barreira natural (Fig. 10C) que contribuiu com a formação de depósitos marinhos elevados. Durante o Holoceno, a transgressão e regressão impediu o avanço do NRM e contribuiu para que a subárea (ii) não fosse retrabalhada/erodida.

Datações pelo método LOE para a subárea (ii) apresentam idade de $6.800 \pm 900$ anos AP. Entretanto, evidências topográficas, pedológicas e biológicas convergem para interpretações mais antigas do que a idade determinada pela datação (Martins, 2009). Dentre as evidências topográficas destacase o contorno do rio no afloramento (subárea i) antes de desaguar no mar (Fig. 10C). A evidência pedológica é a presença do horizonte ortstein a $400 \mathrm{~cm}$ de profundidade que é um indicador de ambientes mais antigos que a Transgressão Santos 
(Martins, 2009; Souza, 2015). A evidência biológica envolve a presença de tubos fósseis de decápodes do gênero Callichirus major (Fig. 10D), encontrados a cerca de $4 \mathrm{~m}$ de profundidade na base do terraço (Martins, 2009; Geraque, 2010). Esses animais vivem atualmente em galerias profundas na zona intermareal, sendo geralmente encontrados abaixo do nível médio das marés (Martin \& Suguio, 1976; Suguio, 1976; Suguio \& Martin, 1978; Peiró,
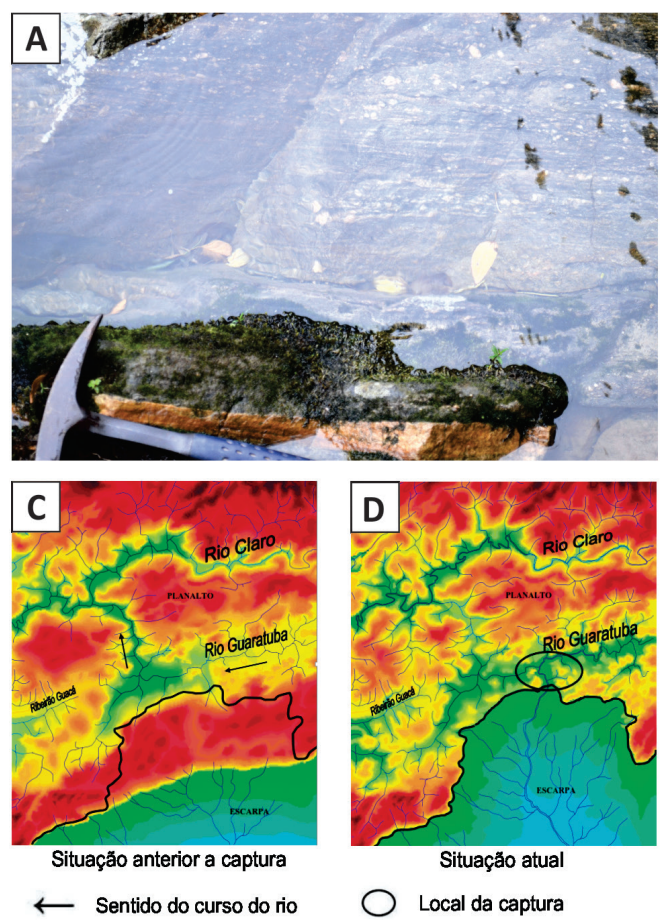

$\leftarrow$ Sentido do curso do rio

Local da captura

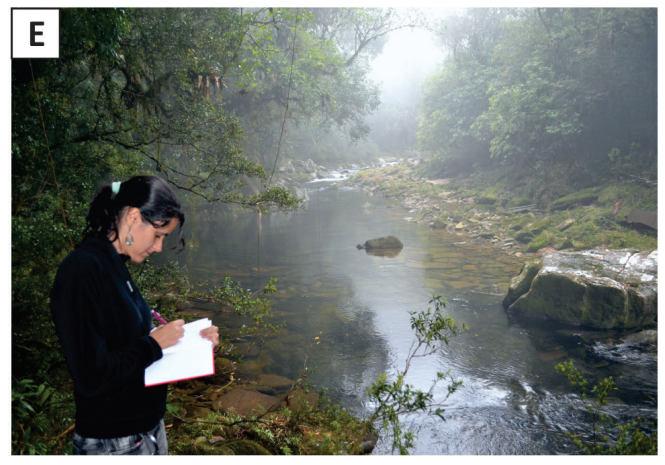

2012). Sua presença indica que o NRM no passado encontrava-se acima do atual, relacionando-se com os depósitos da Formação Cananeia de idade pleistocena. A presença de tubos fósseis são um bom indicador de paleonível marinho, pois encontram-se in situ e indicam a antiga linha de praia, mais avançada continente adentro do que nos dias atuais (Martin \& Suguio 1976; Suguio \& Martin, 1978).
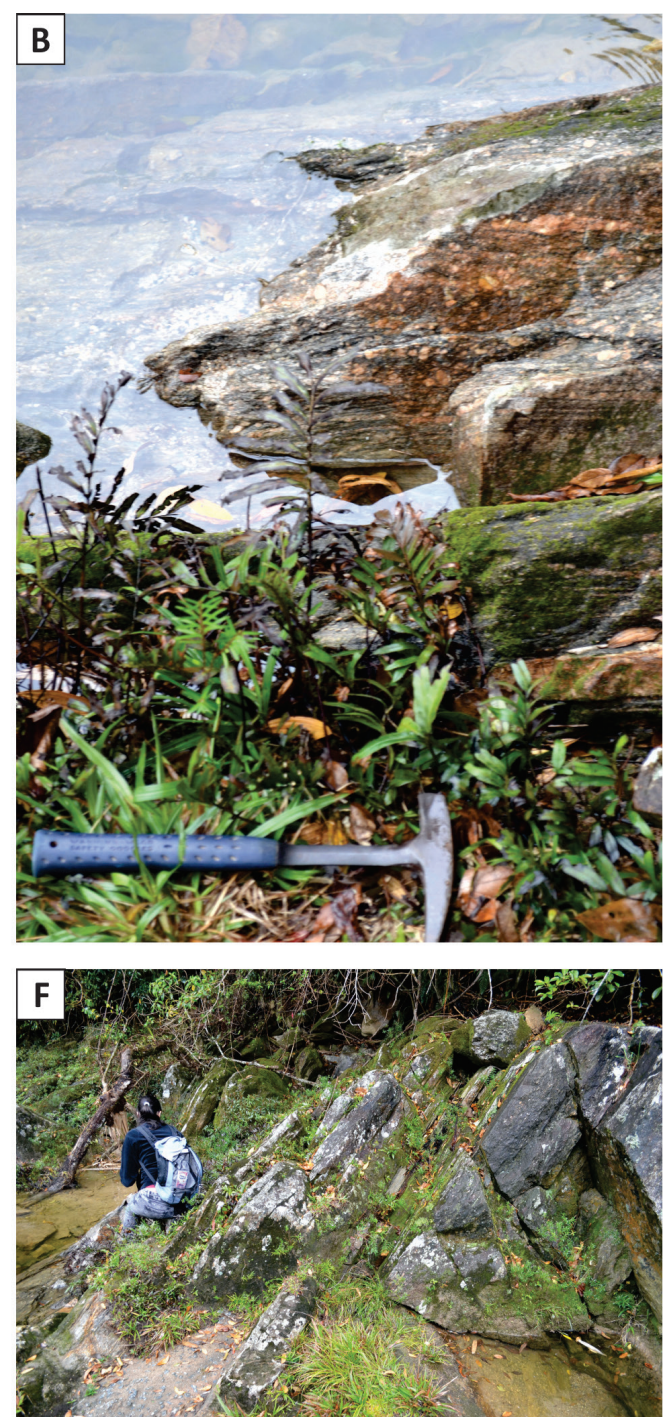

Figura 9. Geossítio Captura Fluvial do Rio Guaratuba. A) Ortognaisse milonítico com injeções de granito róseo; B) Detalhe dos cristais de feldspatos deformados; C) Mapa de identificação do Rio Guaratuba; D) Mapa de identificação do Rio Guaratuba, com destaque para o cotovelo da captura fluvial; E) A curva do Rio Guaratuba ao fundo representa o cotovelo da captura; F) Ortognaisse milonítico com médio a alto ângulo de mergulho. Figuras C e D extraídas de Oliveira (2003).

Figure 9. Geosite River Capture of Guaratuba River. A)Mylonitic orthogneiss with injection of pink granite; B) Details of deformed feldspar crystals; C) Map of identification of Guaratuba River; D) Map of identification of Guaratuba River highlighting the elbow of river capture; E) Mylonitic orthogneiss with medium to high dip angle; F) The curve of Guaratuba River in the background represents the elbow of the river capture. Figures $C$ and D: extracted from Oliveira (2003).

Datações pelo método LOE para a subárea (iii) apresentam idade de $6.600 \pm 500$ anos AP, apesar de a datação ser mais antiga que o último pico da Transgressão Santos, as feições morfológicas e topográficas do depósito indicam idade holocena para esse depósito (Martins, 2009).

As subáreas (i) e (ii) do geossítio são contro- ladas por estruturas tectônicas. O Canal do Rio Itaguaré é controlado pela estrutura E-W; a distribuição geométrica do traço da zona de cisalhamento associada ao embasamento (subárea i) - (Fig. 10C) sugere que seja um prolongamento da ZCC e a subárea (ii) é controlada por dois sistemas de juntas ortogonais na direção E-W e N55E, sendo a erosão 
acentuada associada a esse controle estrutural (Fig. 10E) (Souza, 2015; Garcia et al. 2017).

Quadro 8. Descrição sucinta das características do Geossítio Terraços Marinhos da Praia de Itaguaré.

Chart 8. Brief description of the characteristics of the Geosite Marine Terraces of Itaguaré Beach.

\begin{tabular}{|l|l|}
\hline Localização Geográfica & $\begin{array}{l}\text { Próximo à foz do Rio Itaguaré (0400618 / 7369424), (0400866 / 7369819) e } \\
(0401297 / 7369803)\end{array}$ \\
\hline Tipologia & Área complexa \\
\hline Enquadramento Legal & Parque Estadual Restinga de Bertioga \\
\hline Acesso & $\begin{array}{l}\text { Seguir pela Rod. Manoel Hypólito do Rego (SP-055) até a entrada da Praia de Ita- } \\
\text { guaré }\end{array}$ \\
\hline Dimensão aproximada & 240.000 m² \\
\hline Caracterização sucinta & $\begin{array}{l}\text { Geossítio de área complexa com a presença de um afloramento de gnaisse milonítico } \\
\text { e dois depósitos sedimentares arenosos, um de idade pleistocena e outro holocena }\end{array}$ \\
\hline Litotipo predominante & Depósito sedimentar arenoso \\
\hline Unidade (Perrotta et al., 2005) & Depósitos litorâneos indiferenciados \\
\hline
\end{tabular}

O geossítio possui elevado interesse científico e está inserido no inventário do patrimônio geológico do Estado de São Paulo, sendo nomeado como "Falésias em terraços marinhos Pleistoceno" (Garcia et al., 2017). Seu potencial educativo é voltado para alunos de ensino médio e ensino superior, pois exemplifica os processos de variação do NRM e processos da dinâmica costeira, além de possuir potencial turístico uma vez que se encontra numa praia com ampla visitação turística. Apresenta alta fragilidade por conta da intensa erosão flúviomarinha decorrente das variações da maré, apesar de estar legalmente protegido pelo PERB, e alta vulnerabilidade associada a marcas de pichações que são um dano irreversível à sua integridade (Fig. 10B).

\subsubsection{Sítios de geodiversidade}

A descrição dos sítios de geodiversidade com valor educativo e turístico é apresentada no quadro 9, suas localizações na figura 2 e as ilustrações na figura 11.

\subsection{Avaliação quantitativa do patrimônio geológico}

Para a avaliação quantitativa do patrimônio geológico foram utilizados os métodos propostos por Pereira (2010) e Brilha (2016). Como observado anteriormente, apesar do reduzido número de geossítios e sítios de geodiversidade inventariados no município, optou-se pela quantificação por fazer parte de um projeto maior.

\subsubsection{Método de Pereira (2010)}

0 método avalia o patrimônio geológico num conjunto de vinte parâmetros, valorado entre 0 a 4 pontos (Quadro 10).
Com base nos valores atribuídos a cada um dos parâmetros calculou-se a média ponderada das categorias Vi, Vci, Vtur e Vug (Tab. 1). Os resultados destes cálculos foram utilizados para determinar o Valor de Uso Científico (VUC), Valor Turístico (VUT), Valor de Conservação (VC) e Relevância (R), com base nos quais estabeleceram-se o ranking e a relevância do conjunto de geossítios (Tab. 2).

\subsubsection{Método de Brilha (2016)}

Os geossítios e sítios de geodiversidade representam as ocorrências in situ dos elementos da geodiversidade; os primeiros com elevado valor científico e os últimos com valor educacional, turístico e/ou cultural (Brilha, 2016). De acordo com o autor, a relevância dos geossítios pode ser somente nacional ou internacional, enquanto os sítios de geodiversidade podem ter relevância local, nacional ou internacional.

A quantificação dos geossítios engloba sete parâmetros, que podem ser valorados com $0,1,2$ ou 4 pontos. 0 valor final é obtido atribuindo-se os seguintes pesos a cada um destes parâmetros: A: representatividade (30\%), B: local-tipo (20\%), C: conhecimento científico (5\%), D: integridade (15\%), E: diversidade geológica (5\%), F: raridade (15\%) e G: limitações ao uso (10\%). Os valores atribuídos a cada critério e os cálculos com base nos pesos foram utilizados para estabelecer o ranking dos geossítios (Tab. 3).

A quantificação dos sítios de geodiversidade com potencial educacional leva em conta doze parâmetros. $\mathrm{O}$ valor final é obtido atribuindo-se os seguintes pesos: A: vulnerabilidade (10\%), B: acessibilidade (10\%), C: limitações ao uso (5\%), D: segurança (10\%), E: logística (5\%), F: densidade populacional (5\%), G: associação com outros valo- 
res (5\%), H: beleza cênica (5\%), I: singularidade (5\%), J: condições de observação (10\%), K: potencial didático (20\%) e L: diversidade geológica (10\%). Para o potencial turístico, treze parâmetros são avaliados, sendo os parâmetros A, B, C, D, E, F e
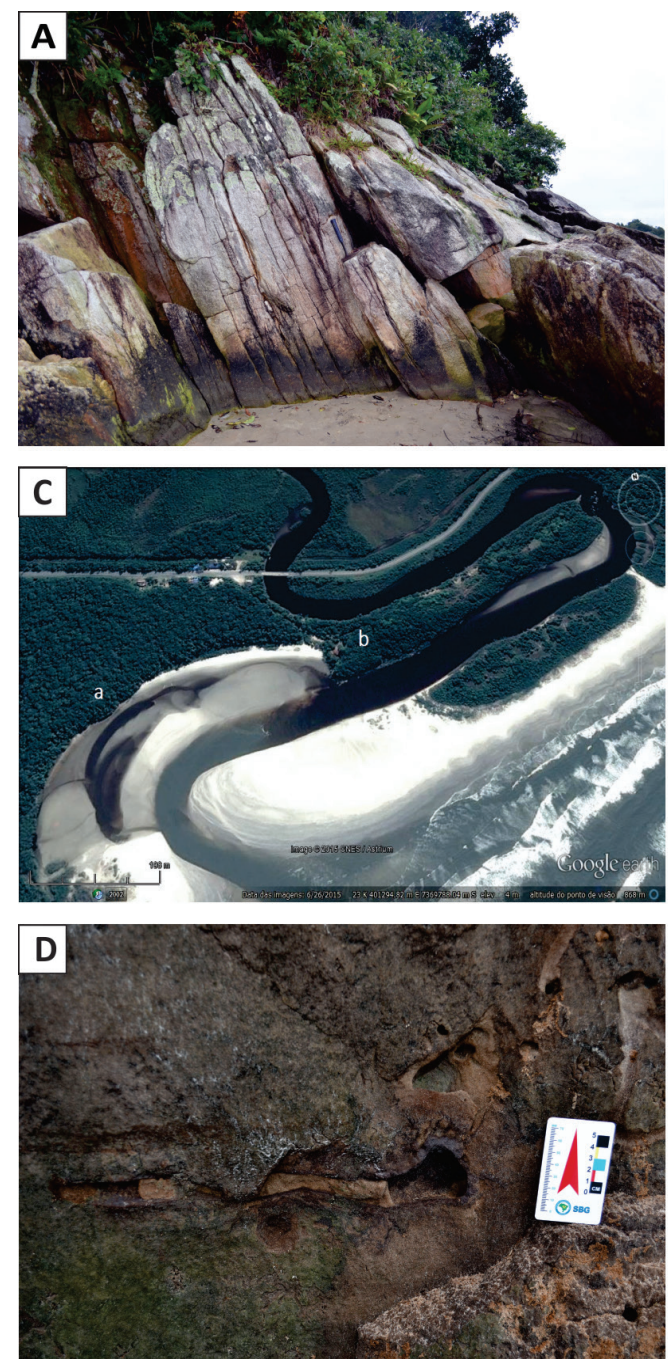

G idênticos ao do potencial educacional, H: beleza cênica (15\%), I: singularidade (10\%), J: condições de observação (5\%), K: potencial interpretativo (10\%), L: nível econômico (5\%) e M: proximidades a zonas recreativas (5\%).
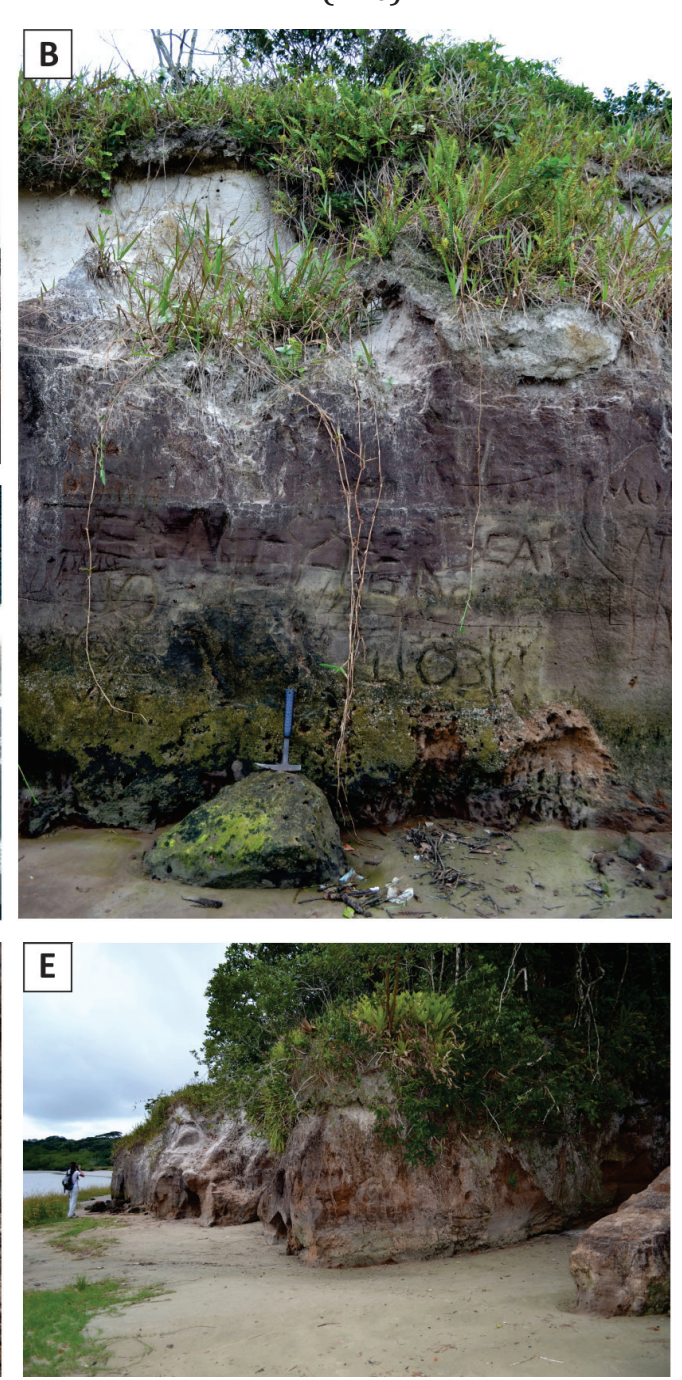

Figura 10. Geossítio Terraços Marinhos da Praia de Itaguaré. A) Milonito paralelo à linha de costa com alto ângulo de mergulho; B) Depósito sedimentar com vegetação típica de restinga, detalhe para os danos causados pelas pichações; C) Foz do Rio Itaguaré: (a) localização da subárea (ii) e (b) contorno do rio na subárea (i) com o canal controlado pela estrutura E-W (Fonte: Google Earth); D) Galeria dos tubos de Callichirus major; E) Subárea (ii) com erosão controlada por sistema de juntas ortogonais.

Figure 10. Geosite Marine Terraces of Itaguaré Beach. A) Mylonite parallel to the coastline with high dip angle; B) Sediment deposits with typical vegetation of restinga. The damage caused by graffiti is highlighting; $C$ ) Itaguaré River mouth: (a) location of subarea (ii) and (b) river boundary in subarea (i) with channel controlled by E-W structure (Source: Google Earth); D) Tubes of Callichirus major; E) Subarea (ii) with erosion controlled by orthogonal joint systems.

Os valores de cada critério e seu respectivo peso foram utilizados para calcular o ranking dos sítios de geodiversidade (Tab. 4).

A avaliação quantitativa do RD tem por objetivo ordenar os geossítios (Tab. 5) e sítios de geodiversidade (Tab. 6) que devem ter prioridade em futuras estratégias de geoconservação (Brilha, 2016). 0 método estabelece cinco parâmetros sendo possível valorá-lo entre 0 e 4 pontos. Para obterse o valor final, os seguintes pesos são atribuídos: A: deterioração de elementos geológicos (35\%), B: proximidade a áreas/atividades com potencial para causar degradação (20\%), C: proteção legal
(20\%), D: acessibilidade (15\%) e E: densidade populacional $(10 \%)$. De acordo com o valor final, o RD pode ser baixo $(<200)$, moderado (201-300) ou alto (301-400).

\section{Discussão}

\subsection{Síntese dos resultados}

O inventário foi realizado pelo método de Brilha (2016). Além das etapas propostas pelo método, foram identificadas previamente as principais 
unidades geológico-estruturais e imagens de satélite (Mucivuna et al., 2015) para definir as áreas potenciais; isso foi extremamente útil pois permitiu uma melhor avaliação da sua representatividade.

Os trabalhos de campo foram realizados a fim de corroborar a inclusão dos sítios potenciais na lista final do inventário do município. Os trabalhos de campo nas áreas potenciais permitiram definir a classificação de cada ponto do inventário, pois em alguns casos, potenciais geossítios foram classificados como sítios de geodiversidade por não se enquadrar no valor científico e sim ter elementos educativos e/ou turísticos superlativos.

Quadro 9. Descrição dos sítios de geodiversidade com valores educativos e turísticos.

Chart 9. Description of geodiversity sites with educational and touristic value.

\begin{tabular}{|c|c|c|c|c|}
\hline Nome & $\begin{array}{l}\text { Gnaisses da Praia de } \\
\text { São Lourenço }\end{array}$ & $\begin{array}{c}\text { Granitos da Praia do } \\
\text { Indaiá } \\
\end{array}$ & $\begin{array}{c}\text { Blocos rolados do Rio } \\
\text { Itatinga } \\
\end{array}$ & $\begin{array}{c}\text { Granitos da Cachoeira } \\
\text { do Guaratuba }\end{array}$ \\
\hline $\begin{array}{c}\text { Localização geográ- } \\
\text { fica }\end{array}$ & $\begin{array}{l}\text { Costão norte da Praia } \\
\text { de São Lourenço } \\
(0398160 / 7367465)\end{array}$ & $\begin{array}{c}\text { Costão norte da } \\
\text { Praia do Indaiá } \\
(0393693 / 7364804)\end{array}$ & $\begin{array}{c}\text { Margem direita } \\
\text { do Rio Itatinga } \\
(0387102 / 7371080)\end{array}$ & $\begin{array}{c}\text { Cachoeira do } \\
\text { Rio Guaratuba } \\
(0404853 / 7375705)\end{array}$ \\
\hline $\begin{array}{c}\text { Tipologia } \\
\text { (Fuertes-Gutiérrez } \\
\text { \& Fernández-Martí- } \\
\text { nez, 2010) }\end{array}$ & Pontual & Pontual & Pontual & Pontual \\
\hline $\begin{array}{c}\text { Enquadramento } \\
\text { Legal }\end{array}$ & $\begin{array}{l}\text { Área de Relevante } \\
\text { Interesse Ecológico } \\
\text { Itaguaré }\end{array}$ & Patrimônio da União & $\begin{array}{l}\text { Parque Estadual Res- } \\
\text { tinga de Bertioga }\end{array}$ & $\begin{array}{l}\text { Parque Estadual Res- } \\
\text { tinga de Bertioga }\end{array}$ \\
\hline Acesso & $\begin{array}{l}\text { Seguir pela Rod. Manoel } \\
\text { Hypólito do Rego (SP- } \\
055 \text { ) até a entrada para } \\
\text { a Praia de São Lourenço }\end{array}$ & $\begin{array}{c}\text { Seguir pela Rod. } \\
\text { Manoel Hypólito do } \\
\text { Rego (SP-055) até a } \\
\text { entrada para o Cantão } \\
\text { do Indaiá }\end{array}$ & $\begin{array}{l}\text { Seguir pela trilha que } \\
\text { se inicia no edifício } \\
\text { principal da Usina de } \\
\text { Itatinga }\end{array}$ & $\begin{array}{c}\text { Seguir até o final da } \\
\text { trilha da Cachoeira do } \\
\text { Guaratuba que se inicia } \\
\text { no Loteamento Costa } \\
\text { do Sol }\end{array}$ \\
\hline $\begin{array}{l}\text { Unidade (Perrotta } \\
\text { et al., 2005) }\end{array}$ & $\begin{array}{c}\text { Depósitos litorâneos } \\
\text { indiferenciados }\end{array}$ & $\begin{array}{c}\text { Depósitos litorâneos } \\
\text { indiferenciados }\end{array}$ & $\begin{array}{l}\text { Unidade granito gnáis- } \\
\text { sica migmatítica }\end{array}$ & $\begin{array}{l}\text { Complexo granítico } \\
\text { Pico do Papagaio }\end{array}$ \\
\hline Descrição geológica & $\begin{array}{l}\text { - Costão de ortognaisse } \\
\text { porfiroblástico com di- } \\
\text { que foliado e dobrado. } \\
\text { - Presença de fraturas e } \\
\text { veios pegmatíticos. } \\
\text { - Blocos de diferentes } \\
\text { dimensões próximo ao } \\
\text { costão. }\end{array}$ & $\begin{array}{l}\text { - Costão de granito } \\
\text { porfirítico com feno- } \\
\text { cristais de feldspato } \\
\text { potássico em contato } \\
\text { com o granito defor- } \\
\text { mado. } \\
\text { - Presença de blocos } \\
\text { próximo ao costão. }\end{array}$ & $\begin{array}{l}\text { - Depósito de blocos } \\
\text { rolados de gnaisse com } \\
\text { diferentes dimensões. }\end{array}$ & $\begin{array}{l}\text { - Lajedo de granito } \\
\text { equigranular em con- } \\
\text { tato com rocha máfica } \\
\text { afanítica porfirítica. } \\
\text { - Erosão diferencial em } \\
\text { forma de marmitas. }\end{array}$ \\
\hline Uso potencial & Educativo & Educativo & Educativo & Turístico \\
\hline $\begin{array}{c}\text { Feições da Geodi- } \\
\text { versidade com po- } \\
\text { tencial educacional } \\
\text { e/ou turístico }\end{array}$ & $\begin{array}{l}\text { - Comportamento me- } \\
\text { cânico das rochas: am- } \\
\text { biente dúctil: dobras, e } \\
\text { rúptil: fraturas. } \\
\text { - Intrusões de veios } \\
\text { pegmatíticos. } \\
\text { - Intemperismo e for- } \\
\text { mação de blocos. } \\
\text { - Granulometria e com- } \\
\text { posição da areia. }\end{array}$ & $\begin{array}{l}\text { - Comportamento } \\
\text { mecânico das rochas: } \\
\text { ambiente dúctil: } \\
\text { deformação, e rúptil: } \\
\text { fraturas. } \\
\text { - Formação de blocos } \\
\text { através do intempe- } \\
\text { rismo e erosão. } \\
\text { - Granulometria e } \\
\text { composição da areia. }\end{array}$ & $\begin{array}{l}\text { - Erosão, transporte e } \\
\text { sedimentação. } \\
\text { - Energia do rio: re- } \\
\text { lação com o tamanho } \\
\text { dos sedimentos. } \\
\text { - Arredondamento dos } \\
\text { grãos: relação com a } \\
\text { área fonte. }\end{array}$ & $\begin{array}{l}\text { - Composição minera- } \\
\text { lógica das rochas. } \\
\text { - Erosão, transporte e } \\
\text { sedimentação. } \\
\text { - Contato litológico com } \\
\text { erosão diferencial. }\end{array}$ \\
\hline $\begin{array}{l}\text { Propostas de ativi- } \\
\text { dades educativas e } \\
\text { turísticas }\end{array}$ & $\begin{array}{l}\text { - Identificar a presença } \\
\text { de dobras e } \\
\text { relacioná-las ao com- } \\
\text { portamento dúctil. } \\
\text { - Identificar fraturas } \\
\text { e relacioná-las com a } \\
\text { formação dos blocos. } \\
\text { - Associar os minerais } \\
\text { presentes no costão e } \\
\text { na areia e relacionar ao } \\
\text { ciclo das rochas. } \\
\text { - Observar a geomorfo- } \\
\text { logia da Planície Costei- } \\
\text { ra e da Serra do Mar. }\end{array}$ & $\begin{array}{l}\text {-Identificar as dife- } \\
\text { rentes litologias. } \\
\text { - Identificar fraturas } \\
\text { e relacioná-las com a } \\
\text { formação dos blocos. } \\
\text { - Associar os minerais } \\
\text { presentes no costão e } \\
\text { na areia e relacionar } \\
\text { ao ciclo das rochas. } \\
\text { - Observar a geomor- } \\
\text { fologia da Planície } \\
\text { Costeira e da Serra } \\
\text { do Mar. }\end{array}$ & $\begin{array}{l}\text { - Explicar a ação da } \\
\text { água sobre os sedi- } \\
\text { mentos transportados. } \\
\text { - Relacionar com o } \\
\text { ciclo das rochas. } \\
\text {-Reconhecer a di- } \\
\text { nâmica de erosão e } \\
\text { sedimentação. } \\
\text {-Identificar o tamanho } \\
\text { e arredondamento dos } \\
\text { grãos e relacionar com } \\
\text { a área fonte e energia } \\
\text { do rio. }\end{array}$ & $\begin{array}{c}\text { - Explicar sobre os } \\
\text { agentes erosivos. } \\
\text {-Relacionar a formação } \\
\text { das marmitas com a } \\
\text { ação da água e da carga } \\
\text { sedimentar. } \\
\text { - Associar a formação } \\
\text { da queda d'água com } \\
\text { o processo de erosão } \\
\text { diferencial. } \\
\text { - Observar a dinâmica } \\
\text { de erosão, transporte e } \\
\text { sedimentação. }\end{array}$ \\
\hline
\end{tabular}



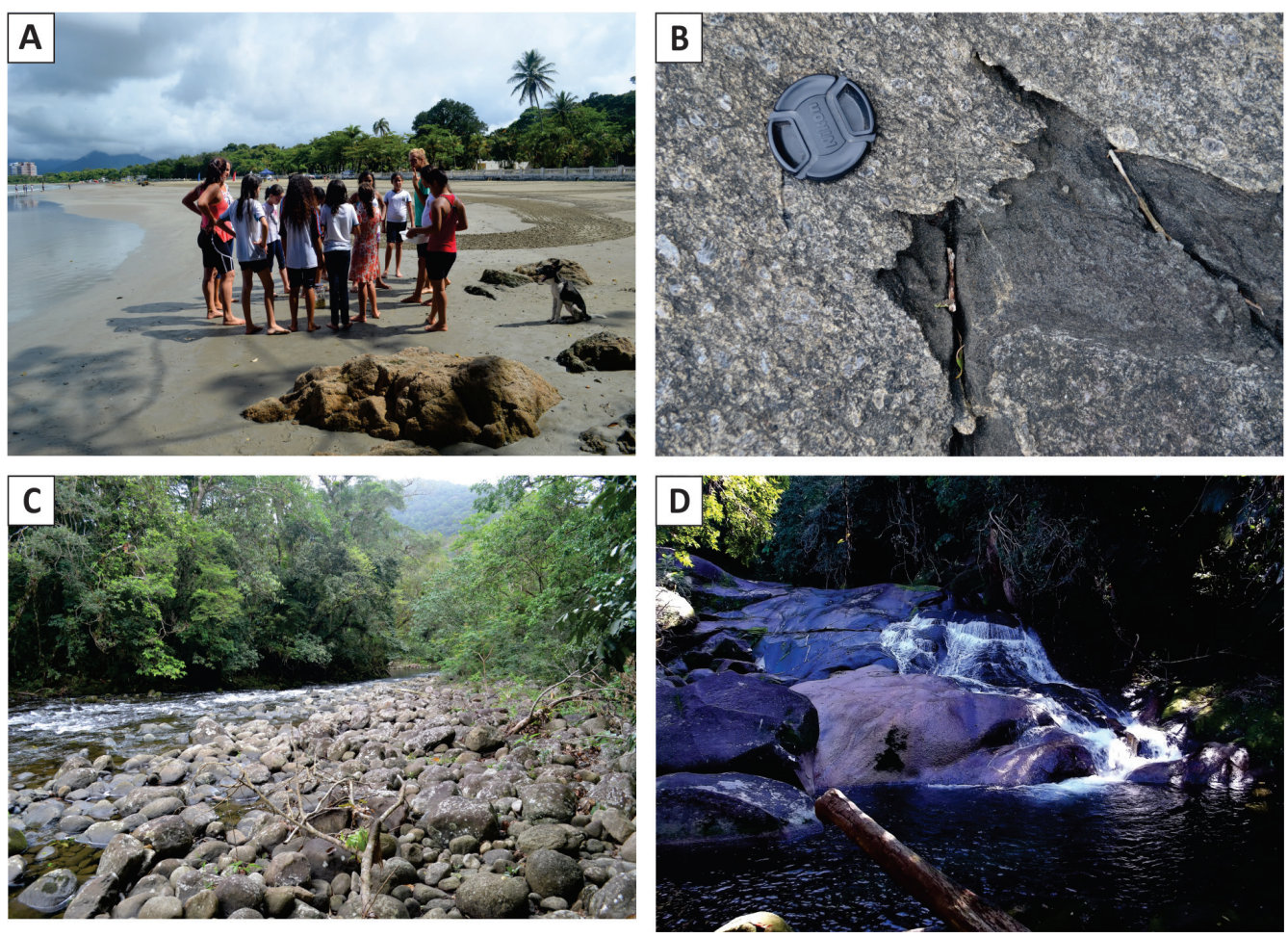

Figura 11. Sítios de Geodiversidade. A) Gnaisses da Praia de São Lourenço; B) Granitos da Praia do Indaiá; C) Blocos Rolados do Rio Itatinga; D) Granitos da Cachoeira do Guaratuba.

Figure 11. Geodiversity sites. A) Gneiss of São Lourenço Beach; B) Granites of Indaiá Beach; C) Rolled Stone Blocks of Itatinga River; D) Granites of Cachoeira do Guaratuba

Quadro 10. Parâmetros da avaliação quantitativa do método de Pereira (2010).

Chart 10. Parameter of quantitative assessment by Pereira's (2010) method.

\begin{tabular}{|c|c|c|c|}
\hline Valor Intrínseco (Vi) & Valor Científico (Vci) & Valor Turístico (Vtur) & Valor de Uso/gestão (Vug) \\
\hline $\begin{array}{l}\text { A1- Vulnerabilidade associada } \\
\text { a processos naturais }\end{array}$ & $\begin{array}{l}\text { B1- Objeto de referências } \\
\text { bibliográficas (grau de conhe- } \\
\text { cimento científico) }\end{array}$ & C1- Aspecto estético & D1- Relevância cultural \\
\hline A2- Abundância / raridade & $\begin{array}{l}\text { B2- Representatividade de ma- } \\
\text { teriais e processos geológicos }\end{array}$ & C2-Acessibilidade & D2- Relevância econômica \\
\hline A3- Integridade & $\begin{array}{l}\text { B3- Diversidade de interesses/ } \\
\text { temas associados }\end{array}$ & $\begin{array}{l}\text { C3- Presença de infraes- } \\
\text { trutura }\end{array}$ & D3- Nível oficial de proteção \\
\hline \multirow[t]{4}{*}{$\begin{array}{l}\text { A4- Variedade de elementos da } \\
\text { geodiversidade }\end{array}$} & B4- Relevância didática & $\begin{array}{l}\text { C4- Existência de utiliza- } \\
\text { ção em curso }\end{array}$ & D4- Passível de utilização econômica \\
\hline & & $\begin{array}{c}\text { C5- Presença de meca- } \\
\text { nismos de controle de } \\
\text { visitantes }\end{array}$ & $\begin{array}{l}\text { D5- Vulnerabilidade associada ao uso antró- } \\
\text { pico }\end{array}$ \\
\hline & & & $\begin{array}{l}\text { D6- População do núcleo urbano mais } \\
\text { próximo }\end{array}$ \\
\hline & & & $\begin{array}{l}\text { D7- Condições socioeconômicas dos núcleos } \\
\text { urbanos mais próximos }\end{array}$ \\
\hline
\end{tabular}

Neste contexto, oito geossítios foram selecionados e contam a história geológica do município, dentre eles seis inserem-se em UCs (Registros Tectônicos da Cachoeira do Sertão, Gnaisses do Canto do Itaguá, Mirante da Serra do Mar, Terraço do Rio Guaratuba, Captura Fluvial do Rio Guaratuba e Terraços Marinhos da Praia de Itaguaré) e dois em áreas pertencentes à União sem qualquer proteção por UCs (Milonitos da Praia de São Lourenço e Terraço Pleistoceno do Rio Itapanhaú). Em relação à distribuição geográfica, quatro encontram-se no Planalto (Registros Tectônicos da Cachoeira do Sertão, Mirante da Serra do Mar, Terraço do Rio Guaratuba e Captura Fluvial do Rio Guaratuba) e quatro na Planície Costeira (Milonitos da Praia de São Lourenço, Gnaisses do Canto do Itaguá, Terraço Pleistoceno do Rio Itapanhaú e Terraços Marinhos da Praia de Itaguaré).

Foram selecionados quatro sítios de geodiversidade, sendo três com valor educativo (Granitos da Praia do Indaiá, Gnaisses da Praia de São Lourenço e Blocos Rolados do Rio Itatinga) e um 
com valor turístico (Granitos da Cachoeira do Guaratuba). Dentre eles, três estão inseridos em UCs (Gnaisses da Praia de São Lourenço, Blocos Ro- lados do Rio Itatinga e Granitos da Cachoeira do Guaratuba). Em relação à distribuição geográfica, todos encontram-se na Planície Costeira.

Tabela 1. Valores atribuídos para cada um dos parâmetros e a média aritmética para os valores intrínsecos (Vi), científico (Vci), turístico (Vtur) e de uso e gestão (Vug) dos geossítios do Município de Bertioga pelo método de Pereira (2010).

Table 1. Values assigned for each parameter and the arithmetic mean for intrinsic (Vi), scientific (Vci), touristic (Vtur) and management and use (Vug) values of geosites in the Bertioga Municipality by Pereira's (2010) method

\begin{tabular}{|c|c|c|c|c|c|c|c|c|c|}
\hline \multicolumn{10}{|c|}{ Quantificação dos geossítios pelo método de Pereira (2010) } \\
\hline & & $\begin{array}{c}\text { Registros } \\
\text { Tectônicos } \\
\text { da Cachoeira } \\
\text { do Sertão }\end{array}$ & $\begin{array}{c}\text { Milonitos } \\
\text { da Praia } \\
\text { de São } \\
\text { Lourenço }\end{array}$ & $\begin{array}{c}\text { Gnaisses do } \\
\text { Canto do } \\
\text { Itaguá }\end{array}$ & $\begin{array}{c}\text { Mirante da } \\
\text { Serra do } \\
\text { Mar }\end{array}$ & $\begin{array}{l}\text { Terraço } \\
\text { Pleistoceno do } \\
\text { Rio Itapanhaú }\end{array}$ & $\begin{array}{c}\text { Terraço do } \\
\text { Rio Guaratuba }\end{array}$ & $\begin{array}{c}\text { Captura } \\
\text { Fluvial } \\
\text { do Rio } \\
\text { Guaratuba }\end{array}$ & $\begin{array}{c}\text { Terraços } \\
\text { Marinhos } \\
\text { da Praia de } \\
\text { Itaguaré }\end{array}$ \\
\hline \multirow{5}{*}{$\mathbf{V i}$} & A1 & 2 & 2 & 2 & 2 & 0 & 2 & 2 & 0 \\
\hline & A2 & 4 & 4 & 4 & 0 & 4 & 0 & 4 & 4 \\
\hline & A3 & 3 & 3 & 3 & 3 & 1 & 3 & 3 & 1 \\
\hline & A4 & 4 & 4 & 4 & 3 & 4 & 4 & 4 & 4 \\
\hline & Média & 3,25 & 3,25 & 3,25 & 2,00 & 2,25 & 2,25 & 3,25 & 2,25 \\
\hline \multicolumn{10}{|c|}{ Média Final $(\mathrm{Vi})=2,72$} \\
\hline \multirow{5}{*}{ Vci } & B1 & 0 & 0 & 0 & 0 & 4 & 4 & 4 & 4 \\
\hline & B2 & 2 & 2 & 2 & 2 & 2 & 2 & 4 & 4 \\
\hline & B3 & 1 & 2 & 2 & 1 & 2 & 1 & 1 & 2 \\
\hline & B4 & 2 & 2 & 2 & 4 & 2 & 4 & 2 & 2 \\
\hline & Média & 1,25 & 1,50 & 1,50 & 1,75 & 2,50 & 2,75 & 2,75 & 3,00 \\
\hline \multicolumn{10}{|c|}{ Média Final (Vci) = 2,13 } \\
\hline \multirow{6}{*}{ Vtur } & $\mathrm{C} 1$ & 2 & 4 & 2 & 4 & 2 & 0 & 2 & 4 \\
\hline & $\mathrm{C} 2$ & 2 & 3 & 3 & 1 & 3 & 2 & 2 & 3 \\
\hline & $\mathrm{C} 3$ & 4 & 0 & 0 & 4 & 0 & 2 & 2 & 0 \\
\hline & $\mathrm{C} 4$ & 4 & 3 & 3 & 4 & 0 & 0 & 0 & 0 \\
\hline & $\mathrm{C} 5$ & 4 & 0 & 0 & 4 & 0 & 4 & 4 & 0 \\
\hline & Média & 3,20 & 2,00 & 1,60 & 3,40 & 1,00 & 1,60 & 2,00 & 1,40 \\
\hline \multicolumn{10}{|c|}{ Média Final (Vtur) = 2,03 } \\
\hline \multirow{8}{*}{ Vug } & D1 & 1 & 1 & 1 & 0 & 1 & 0 & 1 & 1 \\
\hline & D2 & 4 & 4 & 4 & 4 & 4 & 4 & 4 & 4 \\
\hline & D3 & 4 & 0 & 4 & 4 & 0 & 4 & 4 & 4 \\
\hline & D4 & 4 & 4 & 2 & 4 & 2 & 2 & 2 & 2 \\
\hline & D5 & 2 & 2 & 2 & 2 & 0 & 2 & 2 & 0 \\
\hline & D6 & 4 & 4 & 4 & 4 & 4 & 4 & 4 & 4 \\
\hline & D7 & 4 & 4 & 4 & 4 & 4 & 4 & 4 & 4 \\
\hline & Média & 3,29 & 2,71 & 3,00 & 3,14 & 2,14 & 2,86 & 3,00 & 2,71 \\
\hline \multicolumn{10}{|c|}{ Média Final (Vug) = 2,86 } \\
\hline
\end{tabular}

4.2 Considerações sobre os parâmetros da quantificação

\subsubsection{Método de Pereira (2010)}

A escolha dos valores para cada parâmetro resultou na análise minuciosa de cada critério e algumas considerações sobre eles são descritos a seguir.

No valor intrínseco, nenhum geossítio foi classificado com 4 pontos nos parâmetros vulnerabilidade associada a processos naturais (A1) e integridade (A3) uma vez que todo geossítio apresenta alguma vulnerabilidade e nenhum está totalmente íntegro como apresentam os parâmetros "não apresenta qualquer vulnerabilidade decorrente de processos naturais" e "geossítio íntegro e sem qualquer deterioração e sem necessidade de recuperação".

No valor científico, o parâmetro objeto de referências bibliográficas (B1) é passível de mudança frente à publicação de novas pesquisas. Nos critérios representatividade de materiais e processos geológicos (B2) e relevância didática (B4) nenhum geossítio recebeu a valoração 0 , pois o inventário do município é de valor científico e consequentemente com relevância didática, seja para o público geral ou especializado como apresentam os parâmetros "ausência de qualquer aspecto relevante de natureza científica" e "sem relevância didática". 
Tabela 2. Resultado dos cálculos dos valores VUC, VUT, VC e R com o respectivo ranking dos geossítios do Município de Bertioga pelo método de Pereira (2010).

Table 2. Results of calculations of VUC, VUT, VC and R values with the respective ranking of geosites in the Bertioga Municipality by Pereira's (2010) method.

\begin{tabular}{|c|c|c|c|c|c|c|c|c|c|}
\hline \multicolumn{10}{|c|}{ Quantificação da relevância dos geossítios (Pereira, 2010) } \\
\hline & $\begin{array}{c}\text { Registros } \\
\text { Tectônicos } \\
\text { da } \\
\text { Cachoeira } \\
\text { do Sertão }\end{array}$ & $\begin{array}{c}\text { Milonitos } \\
\text { da Praia } \\
\text { de São } \\
\text { Lourenço }\end{array}$ & $\begin{array}{l}\text { Gnaisses } \\
\text { do Canto } \\
\text { do Itaguá }\end{array}$ & $\begin{array}{c}\text { Mirante } \\
\text { da Serra } \\
\text { do Mar }\end{array}$ & $\begin{array}{c}\text { Terraço } \\
\text { Pleistoceno do } \\
\text { Rio Itapanhaú }\end{array}$ & $\begin{array}{c}\text { Terraço } \\
\text { do Rio } \\
\text { Guaratuba }\end{array}$ & $\begin{array}{c}\text { Captura } \\
\text { Fluvial do Rio } \\
\text { Guaratuba }\end{array}$ & $\begin{array}{c}\text { Terraços } \\
\text { Marinhos } \\
\text { da Praia de } \\
\text { Itaguaré }\end{array}$ & Média \\
\hline VUC & 2,05 & 2,20 & 2,20 & 1,85 & 2,40 & 2,55 & 2,95 & 2,70 & 2,36 \\
\hline VUT & 3,23 & 2,29 & 2,16 & 3,30 & 1,46 & 2,10 & 2,40 & 1,93 & 2,36 \\
\hline VC & 2,86 & 2,79 & 2,85 & 2,18 & 2,28 & 2,47 & 3,10 & 2,49 & 2,63 \\
\hline $\mathbf{R}$ & 12,22 & 11,14 & 10,93 & 11,66 & 10,43 & 12,00 & 13,83 & 12,21 & 11,80 \\
\hline $\begin{array}{c}\text { Relevância } \\
\text { dos } \\
\text { Geossítios }\end{array}$ & Nacional & Regional & Regional & Regional & Regional & Nacional & Internacional & Nacional & \\
\hline Ranking & $2^{\circ}$ & 60 & 70 & 5웅 & $8^{\circ}$ & 40 & 10 & $3^{\circ}$ & \\
\hline
\end{tabular}

Tabela 3. Resultado dos cálculos da quantificação de valor científico e ranking da posição dos geossítios do Município de Bertioga pelo método de Brilha (2016).

Table 3. Result of quantification calculations of scientific value and ranking of geosites in the Bertioga Municipality by Brilha's (2016) method.

\begin{tabular}{|c|c|c|c|c|c|c|c|c|}
\hline \multicolumn{9}{|c|}{ Quantificação dos geossítios de valor científico pelo método de Brilha (2016) } \\
\hline $\begin{array}{l}\text { Valor } \\
\text { científico } \\
\text { (VC) }\end{array}$ & $\begin{array}{c}\text { Registros } \\
\text { Tectônicos da } \\
\text { Cachoeira do } \\
\text { Sertão }\end{array}$ & $\begin{array}{c}\text { Milonitos da } \\
\text { Praia de São } \\
\text { Lourenço }\end{array}$ & $\begin{array}{c}\text { Gnaisses do } \\
\text { Canto do } \\
\text { Itaguá }\end{array}$ & $\begin{array}{l}\text { Mirante da } \\
\text { Serra do } \\
\text { Mar }\end{array}$ & $\begin{array}{c}\text { Terraço } \\
\text { Pleistoceno do } \\
\text { Rio Itapanhaú }\end{array}$ & $\begin{array}{c}\text { Terraço } \\
\text { do Rio } \\
\text { Guaratuba }\end{array}$ & $\begin{array}{c}\text { Captura } \\
\text { Fluvial } \\
\text { do Rio } \\
\text { Guaratuba }\end{array}$ & $\begin{array}{c}\text { Terraços } \\
\text { Marinhos } \\
\text { da Praia de } \\
\text { Itaguaré }\end{array}$ \\
\hline A & 4 & 4 & 4 & 4 & 4 & 4 & 4 & 4 \\
\hline B & 1 & 1 & 1 & 1 & 2 & 1 & 2 & 2 \\
\hline C & 0 & 0 & 0 & 0 & 4 & 2 & 4 & 4 \\
\hline D & 4 & 4 & 4 & 4 & 2 & 4 & 4 & 2 \\
\hline $\mathbf{E}$ & 4 & 4 & 4 & 2 & 4 & 4 & 4 & 4 \\
\hline $\mathbf{F}$ & 4 & 4 & 4 & 1 & 4 & 1 & 4 & 4 \\
\hline G & 2 & 4 & 2 & 2 & 4 & 1 & 1 & 2 \\
\hline Média & 300 & 320 & 300 & 245 & 330 & 255 & 330 & 310 \\
\hline Ranking & 50 & 30 & 60 & $8^{\circ}$ & 20 & 70 & 10 & 40 \\
\hline
\end{tabular}

Tabela 4. Resultado dos cálculos da quantificação de valor educativo e turístico dos sítios de geodiversidade do Município de Bertioga pelo método de Brilha (2016).

Table 4. Result of quantification calculations of educational and touristic value of geodiversity sites in the Bertioga Municipality by Brilha's (2016) method.

Quantificação dos sítios da geodiversidade de valor educativo e turístico pelo método de Brilha (2016)

\begin{tabular}{|c|c|c|c|c|c|}
\hline $\begin{array}{l}\text { Potencial uso } \\
\text { educativo }\end{array}$ & $\begin{array}{c}\text { Granitos da Praia } \\
\text { do Indaiá }\end{array}$ & $\begin{array}{l}\text { Gnaisses da Praia } \\
\text { de São Lourenço }\end{array}$ & $\begin{array}{l}\text { Blocos Rolados } \\
\text { do Rio Itatinga }\end{array}$ & $\begin{array}{l}\text { Potencial uso } \\
\text { turístico }\end{array}$ & $\begin{array}{c}\text { Granitos da } \\
\text { Cachoeira do } \\
\text { Guaratuba }\end{array}$ \\
\hline A & 3 & 3 & 3 & $\mathbf{A}$ & 3 \\
\hline B & 1 & 3 & 0 & B & 0 \\
\hline C & 2 & 2 & 2 & C & 2 \\
\hline D & 2 & 2 & 2 & D & 2 \\
\hline $\mathbf{E}$ & 4 & 4 & 4 & $\mathbf{E}$ & 4 \\
\hline $\mathbf{F}$ & 1 & 1 & 1 & $\mathbf{F}$ & 1 \\
\hline G & 3 & 3 & 4 & G & 3 \\
\hline $\mathbf{H}$ & 0 & 0 & 0 & $\mathbf{H}$ & 2 \\
\hline I & 1 & 1 & 1 & I & 1 \\
\hline $\mathbf{J}$ & 3 & 3 & 4 & $\mathbf{J}$ & 2 \\
\hline $\mathbf{K}$ & 2 & 2 & 3 & $\mathbf{K}$ & 3 \\
\hline $\mathbf{L}$ & 3 & 3 & 3 & $\mathbf{L}$ & 1 \\
\hline- & - & - & - & M & 3 \\
\hline Média & 215 & 235 & 240 & Média & 200 \\
\hline Ranking & $3^{\circ}$ & $2^{o}$ & $1^{0}$ & -- & -- \\
\hline
\end{tabular}


Tabela 5. Resultado dos cálculos da quantificação do risco de degradação dos geossítios do Município de Bertioga pelo método de Brilha (2016).

Table 5. Result of quantification calculations of degradation risk of geosites in the Bertioga Municipality by Brilha's (2016) method.

\begin{tabular}{|c|c|c|c|c|c|c|c|c|}
\hline \multicolumn{9}{|c|}{ Quantificação do risco de degradação dos geossítios pelo método de Brilha (2016) } \\
\hline $\begin{array}{c}\text { Risco de } \\
\text { degradação }\end{array}$ & $\begin{array}{c}\text { Registros } \\
\text { Tectônicos da } \\
\text { Cachoeira do } \\
\text { Sertão }\end{array}$ & $\begin{array}{c}\text { Milonitos da } \\
\text { Praia de São } \\
\text { Lourenço }\end{array}$ & $\begin{array}{l}\text { Gnaisses } \\
\text { do Canto } \\
\text { do Itaguá }\end{array}$ & $\begin{array}{l}\text { Mirante da } \\
\text { Serra do } \\
\text { Mar }\end{array}$ & $\begin{array}{c}\text { Terraço } \\
\text { Pleistoceno } \\
\text { do Rio } \\
\text { Itapanhaú }\end{array}$ & $\begin{array}{c}\text { Terraço } \\
\text { do Rio } \\
\text { Guaratuba }\end{array}$ & $\begin{array}{l}\text { Captura } \\
\text { Fluvial } \\
\text { do Rio } \\
\text { Guaratuba }\end{array}$ & $\begin{array}{c}\text { Terraços } \\
\text { Marinhos } \\
\text { da Praia de } \\
\text { Itaguaré }\end{array}$ \\
\hline A & 2 & 2 & 2 & 1 & 3 & 2 & 2 & 3 \\
\hline B & 2 & 4 & 4 & 0 & 2 & 0 & 0 & 4 \\
\hline $\mathbf{C}$ & 1 & 4 & 2 & 1 & 4 & 1 & 1 & 2 \\
\hline D & 2 & 1 & 3 & 0 & 3 & 2 & 2 & 1 \\
\hline E & 1 & 1 & 1 & 1 & 1 & 1 & 1 & 1 \\
\hline Média & 170 & 255 & 245 & 65 & 280 & 130 & 130 & 250 \\
\hline Resultado & Baixo & Moderado & Moderado & Baixo & Moderado & Baixo & Baixo & Moderado \\
\hline
\end{tabular}

Tabela 6. Resultado dos cálculos da quantificação do risco de degradação dos sítios de geodiversidade do Município de Bertioga pelo método de Brilha (2016).

Table 6. Result of quantification calculations of degradation risk of geodiversity sites in the Bertioga Municipality by Brilha's (2016) method.

\begin{tabular}{ccccc}
\hline \multicolumn{5}{c}{ Quantificação do risco de degradação dos sítios de geodiversidade pelo método de Brilha (2016) } \\
\hline $\begin{array}{c}\text { Risco de } \\
\text { degradação }\end{array}$ & $\begin{array}{c}\text { Granitos da Praia do } \\
\text { Indaiá }\end{array}$ & $\begin{array}{c}\text { Gnaisses da Praia de } \\
\text { São Lourenço }\end{array}$ & $\begin{array}{c}\text { Blocos Rolados do } \\
\text { Rio Itatinga }\end{array}$ & $\begin{array}{c}\text { Granitos da Cachoeira do } \\
\text { Guaratuba }\end{array}$ \\
\hline A & 2 & 2 & 2 & 2 \\
B & 4 & 4 & 0 & 0 \\
C & 4 & 2 & 2 & 1 \\
D & 1 & 3 & 0 & 0 \\
E & 1 & 1 & 1 & 100 \\
\hline Média & 255 & 245 & Baixo & Baixo \\
\hline
\end{tabular}

No valor turístico, o parâmetro aspecto estético (C1) foi considerado extremamente subjetivo, como aponta o próprio autor. 0 critério acessibilidade (C2) foi adaptado para o geossítio Terraço do Rio Guaratuba, pois seu acesso é realizado por estrada de terra - adotou-se o valor 2 que indica "acessível a partir de estradas não asfaltadas e trilha com menos de $2 \mathrm{~km}$ de extensão". No parâmetro existência de utilização em curso (C3) há geossítios que se encontram em costões de praias com alto índice de visitação, porém os turistas não vão ao costão na intenção de observar os geossítios.

No valor de uso e gestão, o critério relevância cultural (D1) foi considerado bastante subjetivo, para fins de quantificação atribuiu-se como cultura local somente o uso de toponímias em relação ao nome dos rios e os geossítios que se encontram na Trilha Passo dos Jesuítas. No parâmetro passível de utilização econômica (D4) não há possibilidade de enquadrar o geossítio Milonitos da Praia de São Lourenço, pois ele não se insere em UC e nem possui infraestrutura, por isso, adotou-se o valor 4 que indica "geossítio sem qualquer restrição para utilização, já dotado de alguma infraestrutura e/ ou com utilização em curso" - a escolha se justifica por ser a única opção do método na qual a área não está inserida em UC. No critério vulnerabilidade associada ao uso antrópico (D5) nenhum geossítio foi classificado com a valoração 4 "Pouco ou nada vulnerável, não deverá sofrer deterioração mediante uso ou visitação, podendo ser utilizado sem qualquer restrição", por se acreditar que não há geossítio que pode ser utilizado sem qualquer restrição. No parâmetro condições socioeconômicas dos núcleos urbanos mais próximos (D7) há duas possibilidades de respostas para o município. O IDH do município é 0,730 abaixo da média regional de 0,817, sendo possível a valoração 1 “IDH inferior ao IDH médio da área”. Porém, a média do IDH nacional é 0,727, neste caso, Bertioga tem IDH acima da média nacional sendo possível a pontuação 4 "IDH superior ao IDH médio nacional". Optou-se pelo valor 4 , mas também poderíamos ter optado pelo 1 .

\subsubsection{Método de Brilha (2016)}

Na quantificação dos geossítios, todos foram valorados com 4 pontos no parâmetro representatividade (A), por se considerar que só se justifica se ele for o melhor exemplo da área de estudo. No critério conhecimento científico (C), teses, disser- 
tações, trabalhos publicados em eventos nacionais e outros tipos de publicação que não sejam artigos de revistas internacionais, nacionais e resumos apresentados em eventos internacionais não se aplicam.

Na quantificação dos sítios de geodiversidade de valor educativo e turístico as seguintes considerações foram elencadas: nenhum sítio foi valorado com a pontuação 4 nos parâmetros vulnerabilidade (A) "os elementos geológicos do sítio não apresentam possibilidade de deterioração por atividades antrópicas" e limitações ao uso (C) "o sítio não tem limitações a ser usado por estudantes e turistas", por se acreditar que todo sítio é passível de deterioração devido ao uso ilimitado por atividades antrópicas. No critério acessibilidade (B) não há possibilidade de valoração para sítios que se localizam a mais de $1 \mathrm{~km}$ de distância. Para sítios com potencial turístico esse valor deveria ser maior, pois podem inserir-se em extensas trilhas ecoturísticas. No parâmetro singularidade (I) as opções para valoração têm escala nacional e em inventários de áreas restritas esses parâmetros não valorizam a região.

Para a quantificação do RD observou-se que o critério acessibilidade (D) não contempla alguns sítios do município, pois não há opção para acessos realizados por trilhas ecoturísticas.

\subsection{Resultados da quantificação e comparação do ranking de relevância dos geossítios}

O método de Pereira (2010) possui como fa- tor determinante para definir a relevância dos geossítios a média da relevância para o conjunto de geossítios, sendo possível classificar a relevância dos geossítios em internacional, nacional, regional ou local.

De acordo com o método de Pereira (2010) um geossítio obteve relevância internacional (Captura Fluvial do Rio Guaratuba), três relevância nacional (Registros Tectônicos da Cachoeira do Sertão, Terraços Marinhos da Praia de Itaguaré e Terraço do Rio Guaratuba) e quatro relevância regional (Mirante da Serra do Mar, Milonitos da Praia de São Lourenço, Gnaisses do Canto do Itaguá e Terraço Pleistoceno do Rio Itapanhaú), (Tab. 2).

No método de Brilha (2016), os geossítios Captura Fluvial do Rio Guaratuba e Terraço Pleistoceno do Rio Itapanhaú obtiveram a mesma média e ficaram empatados na 1 a posição, os geossítios Registros Tectônicos da Cachoeira do Sertão e Gnaisses do Canto do Itaguá também ficaram empatados na 5a posição, (Tab. 3). Para fins de classificação e posterior comparação com o método de Pereira (2010), foi utilizado o parâmetro integridade (D) para definir a $1^{\underline{a}}$ e $2^{\underline{a}}$ posição, para definir a $5^{\underline{a}}$ e $6^{\underline{a}}$ posição o critério adotado foi o uso turístico, não foi utilizado nenhum critério do método de Brilha (2016), pois os geossítios em questão obtiveram as mesmas pontuações em todos os parâmetros.

0 ranking de relevância dos geossítios pelo método de Pereira (2010) e Brilha (2016) somente foi idêntico para o geossítio Captura Fluvial do Rio Guaratuba (Quadro 11).

Quadro 11. Comparação entre o ranking de relevância dos geossítio pelos métodos de Pereira (2010) e Brilha (2016). Chart 11. Comparison between relevance ranking of geosites by Pereira's (2010) and Brilha's (2016) methods.

\begin{tabular}{|c|c|c|}
\hline Posição & Método de Pereira (2010) & Método de Brilha (2016) \\
\hline $\mathbf{1} \mathbf{o}$ & Captura Fluvial do Rio Guaratuba & Captura Fluvial do Rio Guaratuba \\
\hline $\mathbf{2} \mathbf{o}$ & Registros Tectônicos da Cachoeira do Sertão & Terraço Pleistoceno do Rio Itapanhaú \\
\hline $\mathbf{3}^{\mathbf{o}}$ & Terraços Marinhos da Praia de Itaguaré & Milonitos da Praia de São Lourenço \\
\hline $\mathbf{4}^{\mathbf{o}}$ & Terraço do Rio Guaratuba & Terraços Marinhos da Praia de Itaguaré \\
\hline $\mathbf{5} \mathbf{o}$ & Mirante da Serra do Mar & Registros Tectônicos da Cachoeira do Sertão \\
\hline $\mathbf{6} \mathbf{o}$ & Milonitos da Praia de São Lourenço & Gnaisses do Canto do Itaguá \\
\hline $\mathbf{7 0}$ & Gnaisses do Canto do Itaguá & Terraço do Rio Guaratuba \\
\hline $\mathbf{8} \mathbf{o}$ & Terraço Pleistoceno do Rio Itapanhaú & Mirante da Serra do Mar \\
\hline
\end{tabular}

Convém destacar que o método de Pereira (2010) além da relevância científica, leva em consideração também o uso turístico para determinar sua relevância, enquanto o método de Brilha (2016) utiliza somente o valor científico para os geossítios.

A análise dos parâmetros responsáveis pelo resultado da posição de cada geossítio é apresentada a seguir de acordo com a ordem cronológica.

Registros Tectônicos da Cachoeira do Sertão: pelo método de Pereira foi classificado em $2^{\circ}$ e em Brilha em 5․ 0 parâmetro representatividade de materiais e processos geológicos (B2) de Pereira e limitações ao uso (G) de Brilha fez com que dimi- 
nuísse sua pontuação, pois no método de Pereira o geossítio não é utilizado como exemplo clássico e no método de Brilha há limitações de amostragem.

Milonitos da Praia de São Lourenço: pelo método de Pereira foi classificado em $6^{\circ}$ e em Brilha em 3‥ O parâmetro limitações ao uso $(G)$ de Brilha aumentou seu valor pois não há limitações para retirada de amostras. No método de Pereira os parâmetros presença de infraestrutura (C3) e nível oficial de proteção (D3) fizeram com que o geossítio ficasse numa posição inferior pois não há infraestrutura, nem está inserido em UC.

Gnaisses do Canto do Itaguá: pelo método de Pereira foi classificado em 7ํㅜ e pelo de Brilha em 6‥ Os parâmetros representatividade de materiais e processos geológicos (B2), presença de infraestrutura (C3) e presença de mecanismos de controle de visitantes (C5) de Pereira diminuíram seu valor pois não é utilizado como exemplo clássico, não há infraestrutura, nem controle de visitantes; o critério limitações ao uso (G) de Brilha fez com que diminuísse seu valor pois há limitações de amostragem.

Mirante da Serra do Mar: pelo método de Pereira foi classificado em $5^{\circ}$ e no de Brilha em $8^{\circ}$. Os parâmetros abundância/raridade (A2), representatividade de materiais e processos geológicos (B2) e acessibilidade (C2) do método de Pereira classificaram-no numa posição intermediária, pois não é o único exemplo na área, nem exemplo clássico e seu acesso é feito por trilha extensa. No método de Brilha os parâmetros diversidade geológica (E), raridade (F) e limitações ao uso (G) o classificaram em $8^{\circ}$, pois apresenta menos aspectos de interesses geológicos do que os demais geossítios, não é o único exemplo da área e possui limitações para retirada de amostras.

Terraço Pleistoceno do Rio Itapanhaú: no método de Pereira foi classificado em $8^{\circ}$ e no de Brilha em $2^{\circ}$. Os parâmetros vulnerabilidade associada a processos naturais (A1), integridade (A3), representatividade de materiais e processos geológicos (B2), presença de infraestrutura (C3), existência de utilização em curso (C4), presença de mecanismos de controle de visitantes (C5), nível oficial de proteção (D3) e vulnerabilidade associada ao uso antrópico (D5) de Pereira classificaram-no em 8우 devido à elevada vulnerabilidade, por estar deteriorado, não ser exemplo clássico, não apresentar infraestrutura, não ser utilizado turisticamente, não ter controle de acesso, não estar protegido por UC e ser susceptível a impactos por visitação turística. No método de Brilha o parâmetro integridade (D) diminuiu seu valor, pois ele não está bem preservado. 0 fato de não estar inserido em UC e con- sequentemente não possuir limitações para amostragem o classificou numa das primeiras posições no método de Brilha, sendo que o parâmetro similar do método de Pereira fez com que obtivesse a última posição.

Terraço do Rio Guaratuba: no método de Pereira foi classificado em $4^{\circ}$ e em Brilha em 7ํ․ Os parâmetros abundância/raridade (A2), aspecto estético (C1), existência de utilização em curso (C4) e passível de utilização econômica (D4) de Pereira classificaram-no numa posição intermediária, pois não é o único exemplo na área, não possui apelo cênico e não há utilização em curso. Os parâmetros raridade (F) e limitações ao uso (G) de Brilha contribuíram para que ficasse na penúltima posição, pois não é o único exemplo na área e a autorização para trabalhos de campo e a retirada de amostra é muito difícil.

Captura Fluvial do Rio Guaratuba: nos dois métodos foi classificado em 1 o lugar, no método de Pereira possui relevância de nível internacional.

Terraços Marinhos da Praia de Itaguaré: no método de Pereira foi classificado em 3 o e em Brilha em 4o. Os parâmetros vulnerabilidade associada a processos naturais (A1), integridade (A3), presença de infraestrutura (C3), existência de utilização em curso (C4), presença de mecanismos de controle de visitantes (C5) e vulnerabilidade associada ao uso antrópico (D5) do método de Pereira diminuíram sua posição, pois apresenta elevada vulnerabilidade aos processos naturais, está deteriorado, não há infraestrutura, não é utilizado turisticamente, não possui controle de acesso, está susceptível às ameaças antrópicas e sem uso atual. Pelo método de Brilha o critério limitações ao uso (G) classificaram-no numa pontuação menor, pois só é possível realizar trabalhos de campo e amostragem após autorização da UC.

Os geossítios com publicações (Terraço Pleistoceno do Rio Itapanhaú, Terraço do Rio Guaratuba, Captura Fluvial do Rio Guaratuba e Terraços Marinhos da Praia de Itaguaré) obtiveram, em alguns casos, valores mais elevados. No método de Pereira encontram-se na $8^{\circ}$, $4^{\circ}$,, $1^{\circ}$ e $3^{\circ}$ o posição, e no de Brilha na 2oㅜ $7^{\circ}, 1^{\circ}$ e e $4^{\circ}$ posição. Em ambos os métodos, três entre quatro geossítios foram classificados nas quatro primeiras posições.

\subsection{Resultados da quantificação e ranking de rele- vância dos sítios de geodiversidade}

A quantificação e o ranking de relevância dos sítios de geodiversidade foi realizado somente pelo método de Brilha (2016). A análise do resultado de cada sítio de geodiversidade será apresentada 
a seguir de acordo com a ordem de classificação (Tab. 4).

Blocos Rolados do Rio Itatinga: foi classificado em $1^{\circ}$ lugar. 0 parâmetro acessibilidade (B) fez com que sua pontuação não fosse maior, pois o acesso é feito por trilha extensa.

Gnaisses da Praia de São Lourenço: foi classificado em $2^{\circ}$ lugar. Os parâmetros associação com outros valores $(G)$, condições de observação (J) e potencial didático (K) o classificaram numa posição intermediária, pois não possui elementos culturais e ecológicos próximos, a observação não está em boas condições e o potencial didático é para alunos de ensino secundário.

Granitos da Praia do Indaiá: foi classificado em $3^{\circ}$ lugar. Os parâmetros acessibilidade (B), associação com outros valores $(G)$, condições de observação (J) e potencial didático (K) classificaramno na última posição, pois não tem acesso direto por estrada, não possui elementos culturais e ecológicos próximos, as condições de observação não estão boas e os elementos de potencial didático são para alunos de ensino secundário.

Granitos da Cachoeira do Guaratuba: os parâmetros acessibilidade (B) e singularidade (I) diminuíram seu valor, pois o acesso é feito por trilha extensa e os aspectos de singularidade são comuns no país.

A quantificação dos sítios de geodiversidade (Brilha, 2016) possibilitou avaliar o valor de uso educativo e turístico. Como houve somente um sítio com potencial turístico não foi possível estabelecer um ranking, pois não é possível agrupá-los com os de valor educativo por possuir usos, parâmetros e pesos diferentes.

\subsection{Resultados da quantificação do RD dos geossí-} tios e sítios de geodiversidade

A quantificação do RD proposta em Brilha (2016) possibilitou avaliar os sítios que se encontram em maior risco (Tab. 5 e 6). De acordo com os resultados, nenhum local possui RD alto, pois a maioria deles já é protegido pelas UCs.

Dentre os oito geossítios, quatro possuem moderado (Milonitos da Praia de São Lourenço, Gnaisses do Canto do Itaguá, Terraço Pleistoceno do Rio Itapanhaú e Terraços Marinhos da Praia de Itaguaré) e quatro baixo RD (Registros Tectônicos da Cachoeira do Sertão, Mirante da Serra do Mar, Terraço do Rio Guaratuba e Captura Fluvial do Rio Guaratuba), estando seis inseridos em UCs. Dos quatro sítios de geodiversidade, dois possuem moderado (Granitos da Praia do Indaiá e Gnaisses da Praia de São Lourenço) e dois baixo RD (Blocos
Rolados do Rio Itatinga e Granitos da Cachoeira do Guaratuba) e três inserem-se em UCs. Dentre os sítios que não estão protegidos pelas UCs todos possuem RD moderado; dentre os protegidos por UCs seis possuem RD baixo e três possuem RD moderado, pois localizam-se em praias muito movimentadas do município, sem controle de visitantes e com potencial para gerar degradação.

Os resultados do RD devem ser utilizados em conjunto com o ranking da relevância, para determinar as prioridades de gestão dos geossítios e sítios de geodiversidade.

\section{Conclusões}

A geodiversidade presente no Município de Bertioga está representada por meio de oito geossítios e quatro sítios de geodiversidade que foram inventariados e quantificados. Eles representam a história geológica do município e os elementos de interesse podem ser identificados em cada sítio.

A análise dos métodos propostos para a quantificação dos geossítios e sítios de geodiversidade mostrou que, apesar de possuírem parâmetros distintos, precisam ser melhorados e adaptados de acordo com o objetivo do trabalho e o contexto geológico da área.

Os resultados da quantificação diferem um pouco entre si, porém são eficazes para o objetivo do trabalho. A associação dos resultados da relevância dos sítios com o RD (Brilha, 2016) mostrase como uma excelente ferramenta para priorizar as futuras estratégias de geoconservação. Os resultados obtidos na quantificação do RD são concordantes com a realidade observada em campo. Os sítios que não estão protegidos por nenhuma UC possuem o RD moderado, relacionado à falta de medidas legais para conservação dos mesmos.

Mesmo estando contemplada no Sistema Nacional de Unidades de Conservação - SNUC, as UCs do município têm por prioridade a conservação da biodiversidade e, atualmente, não há qualquer proposta para a conservação da geodiversidade. Observou-se que mesmo os sítios protegidos pelas UCs estão sujeitos à moderadas ou elevadas ameaças naturais (Terraço Marinho da Praia de Itaguaré) e/ou antrópicas (Gnaisses da Praia do Itaguá, Terraços Marinhos da Praia de Itaguaré, Gnaisses da Praia de São Lourenço e Granitos da Cachoeira do Guaratuba), pois na maioria das vezes, a geodiversidade é vista como algo duradouro e que não sofre ameaças. Contudo, os resultados mostram que vários sítios estão sujeitos a ameaças antrópicas e a fragilidades naturais mesmo no âmbito 
das UCs. É preciso entender a importância da geodiversidade e fazer cumprir a lei do SNUC para a conservação e gestão dos geossítios e sítios de geodiversidade.

Esse trabalho não pretende esgotar as discussões sobre a temática no município. Espera-se que os temas relacionados à geodiversidade sejam incluídos pelas UCs presentes em seus conceitos de meio natural, juntamente com os aspectos da biodiversidade, de modo que seja possível elaborar propostas de conservação conjuntas. No âmbito governamental, espera-se contribuir para a criação de políticas públicas que orientem o planejamento e o ordenamento territorial e que as etapas previstas em estratégias de geoconservação sejam efetivadas, contribuindo para a conservação da geodiversidade do município.

Agradecimentos. Os resultados deste trabalho são parte da Dissertação de Mestrado da primeira autora junto ao Programa de Pós-Graduação em Mineralogia e Petrologia, do Instituto de Geociências da Universidade de São Paulo. As autoras agradecem o apoio da Pró-Reitoria de Pesquisa da Universidade de São Paulo, por meio do Programa de Incentivo à Pesquisa, que permitiu a criação do Núcleo de Apoio à Pesquisa em Patrimônio Geológico e Geoturismo (GeoHereditas), ao Conselho Nacional de Desenvolvimento Científico e Tecnológico (CNPq) pela bolsa de mestrado concedida (Processo 134376/2014-5) e à Fundação de Amparo à Pesquisa do Estado de São Paulo (FAPESP) por meio do Processo 2011/17261-6.

\section{Referências}

Ab'Saber, A.N. 1950. A Serra do Mar e a Mata Atlântica em São Paulo. Boletim Paulista de Geografia, 4: 6170.

Ab'Saber, A.N. 2003. Os domínios da natureza no Brasil: potencialidades paisagísticas. São Paulo, Ateliê Editorial, $160 \mathrm{p}$.

Ab'Saber, A.N. 2005. Litoral do Brasil / Brazilian coast. São Paulo, Metalivros, 281 p.

Ab'Saber, A.N. 2006. Brasil: paisagens de exceção: o litoral e o pantanal Mato-Grossense: patrimônios básicos. São Paulo, Ateliê Editorial, 182 p.

Almeida, F.F.M. 1964. Os fundamentos geológicos do relevo paulista. Boletim do Instituto Geográfico e Geológico, 41: 169-263.

Almeida, F.F.M. \& Carneiro, C.D.R. 1998. Origem e evolução da Serra do Mar. Revista Brasileira de Geociências, 28(2): 135-150.

Almeida, F.F.M., Hasui, Y., Brito Neves, B.B. \& Fuck, R.A. 1977. Províncias estruturais brasileiras. In: SIMPÓSIO DE GEOLOGIA DO NORDESTE, 8., 1977, Campina Grande, Boletim Especial, p. 12-13.

Almeida, F.F.M., Hasui, Y., Brito Neves, B.B. \& Fuck, R.A. 1981. Brazilian Structural Provinces: an introduc- tion. Earth-Science Reviews, 17(1/2): 1-29.

Arruda, K.E.C., Garcia, M.G.M. \& Del Lama, E.A. 2015. Geological Heritage Inventory as a Subsidy for Geotourism: Caraguatatuba - São Paulo State, Brazil. In: INTERNATIONAL PROGEO SYMPOSIUM, 8., 2015, Reykjavik, ProGEO programme and abstracts, p. 6869.

Brilha, J. 2005. Patrimônio geológico e geoconservação: a conservação da natureza na sua vertente geológica. Braga, Palimage Editora, 190p.

Brilha, J. 2016. Inventory and Quantitative Assessment of Geosites and Geodiversity Sites: a Review. Geoheritage, 8(2): 119-134.

Brilha, J., Alcalá, L., Almeida, A., Araújo, A., Azeredo, A., Azevedo, M.R., Barriga, F., Brum da Silveira, A., Cabral, J., Cachão, M., Caetano, P., Cobus, A., Coke, C., Couto, H., Crispim, J., Cunha, P.P., Dias, R., Duarte, L.V., Dória, A., Falé, P., Ferreira, N., Ferreira Soares, A., Fonseca, P., Galopim de Carvalho, A., Gonçalves, R., Granja, H., Henriques, M.H., Kullberg, J.C., Kullberg, M.C., Legoinha, P., Lima, A., Lima, E., Lopes, L., Madeira, J., Marques, J.F., Martins, A., Martins, R., Matos, J., Medina, J., Miranda, R., Monteiro, C., Moreira, M., Moura, D., Neto Carvalho, C., Noronha, F., Nunes, J.C., Oliveira, J.T., Pais, J., Pena dos Reis, R., Pereira, D., Pereira, P., Pereira, Z., Piçarra, J., Pimentel, N., Pinto de Jesus, A., Prada, S., Prego, A., Ramalho, L., Ramalho, M., Ramalho, R., Relvas. J., Ribeiro, A., Ribeiro, M.A., Rocha, R., Sá, A., Santos, V., Sant'Ovaia, H., Sequeira, A., Sousa, M., Terrinha, P., Valle Aguado, B. \& Vaz, N. 2010. 0 inventário nacional do património geológico: abordagem metodológica e resultados. E-Terra, 18(1):1-4.

CEPAGRI. Centro de Pesquisas Meteorológicas e Climáticas Aplicadas à Agricultura. 2014. Disponível em: <http://www.cpa.unicamp.br/outras-informacoes/ clima_muni_072.html>. Acesso em: 17 nov. 2014.

Christofoletti, A. 1975. Capturas fluviais. In: Enciclopédia Mirador Internacional. São Paulo-Rio de Janeiro, Encyclopedia Britânica do Brasil, p. 2049-2051.

Conti, J.B. \& Furlan, S.A. 2005. Geoecologia: o clima, os solos e a biota. In: Ross, J.L.S. (org.) Geografia do Brasil. São Paulo, Edusp, p. 67-209.

Cordani, U.G., Delhal, J. \& Ledent, D. 1973. Orogeneses superposeés dans le Précambrien du Brésil sud-oriental (états du Rio de Janeiro et Minas Gerais). Revista Brasileira de Geociências, 3(1): 1-22.

Ellis, N. 2008. A history of the Geological Conservation Review. In: Burek, C.V. \& Prosser, C.D. (Ed.). The History of Geoconservation. London, The Geological Society, p.123-135.

Fuertes-Gutiérrez, I. \& Fernández-Martínez, E. 2010. Geosites Inventory in the Leon Province (Northwestern Spain): a Toll to Introduce Geoheritage into Regional Environmental Management. Geoheritage, 2: 57-75.

Garcia, M.G.M. 2012. Gondwana Geodiversity and Geological Heritage: Examples from the North Coast of São Paulo State, Brazil. Anuário do Instituto de Geociências, 35: 101-111.

Garcia, M.G.M., Martins, L., Del Lama, E.A. \& Bourotte, 
C. 2014. O Inventário do patrimônio geológico da região costeira do Estado de São Paulo: base metodológica, adaptações e considerações. In: CONGRESSO BRASILEIRO DE GEOLOGIA, 47., 2014, Salvador. Anais do $47^{\circ}$ Congresso Brasileiro de Geologia, p. 49.

Garcia, M.G.M., Brilha, J., Lima, F.F., Vargas, J.C., PérezAguilar, A.P., Duleba, W., Fernandes, L.A., Fiertz, M.S.M., Martins, L., Raposo, M.I.B., Ricardi-Branco, F., Ross, J.L.S. \& Sallum, W. 2015. The inventory of geological heritage of the State of São Paulo, Brazil: Methodological basis and preliminar results. In: INTERNATIONAL PROGEO SYMPOSIUM, 8, 2015, Reykjavík, ProGEO programme and abstracts, p. 8485.

Garcia, M.G.M., Brilha, J., Lima, F.F., Vargas, J.C., Pérez-Aguillar, A., Alves, A., Campana, G.A.C., Duleba, W., Faleiros, F.M., Fernandes, L.A., Fierz, M.S.M., Garcia, M.J., Janasi, V.A., Martins, L., Raposo, M.I.B., Ricardi-Branco, F., Ross, J.L.S., Sallum Filho, W., Souza, C.R.G., Bernardes-de-Oliveira, M.E.C., Neves, B.B.B, Campos Neto, M.C., Christofoletti, S.R., Henrique-Pinto, R., Lobo, H.A.S., Machado, R., Passarelli, C.R., Perinotto, J.A.J., Ribeiro, R.R. \& Shimada, H. 2017. The Inventory of Geological Heritage of the State of São Paulo, Brazil: Methodological Basis, Results and Perspectives. Geoheritage. doi:10.1007/ s12371-016-0215-y.

Garcia-Cortéz, A. \& Carcavilla Urquí, L. 2009. Documento metodológico para la elaboración del inventario español de lugares de interés geológico (IELIG). Disponível em: < http://www.igme.es/patrimonio/ novedades / METODOLOGIA\%20IELIG\%2 0web. pdf>. Acesso em: 13 jan. 2016.

Geraque, E. 2010. Cuidado, praia em movimento. Unesp ciência, 7: 36-41.

Gray, M. 2004. Geodiversity: Valuing and conserving abiotic nature. Londres, John Wiley \& Sons, 434p.

Gray, M. 2005. Geodiversity and Geoconservation: What, Why and How? The George Wright Forum, 22(3): 4-12.

Gray, M. 2013. Valuing and conserving abiotic nature. Londres, John Wiley \& Sons, 508 p.

Heilbron, M., Pedrosa-Soares, A.C., Campos Neto, M.C., Silva, L.C., Trouw, R.A.J. \& Janasi, V.A. 2004. Província Mantiqueira. In: Mantesso-Neto, V., Bartorelli, A., Carneiro, C.D.R. \& Brito-Neves, B.B. (Org.). Geologia do Continente Sul-Americano: Evolução da obra de Fernando Flávio Marques de Almeida. São Paulo, Beca, p. 203-234.

IBGE. Instituto Brasileiro de Geografia e Estatística. 2010. Censo demográfico. Disponível em: <http:// censo2010.ibge.gov.br>. Acesso em: 12 out. 2014.

Instituto Polis. 2013. Diagnóstico Urbano Socioambiental: Município de Bertioga. São Paulo, Instituto Polis, 486p.

IUGS. International Union of Geological Sciences. 2016. Disponível em: <http:// http://geoheritage-iugs. mnhn.fr/index.php?catid=4\&blogid $=1>$. Acesso em: 10 jan 2016.

Lima, F.F. 2008. Proposta Metodológica para a Inventa- riação do Patrimônio Geológico Brasileiro. Braga, 94p. Dissertação de Mestrado, Escola de Ciências, Universidade do Minho.

Maffra, C.Q.T. 2000. Geologia estrutural do embasamento cristalino da região de São Sebastião, SP: evidências de um domínio transpressivo. São Paulo, 113p. Dissertação de Mestrado, Programa de Pós-graduação em Geoquímica e Geotectônica, Instituto de Geociências, Universidade de São Paulo.

Martin, L. \& Suguio, K. 1976. 0 Quaternário Marinho do Litoral do Estado de São Paulo. In: CONGRESSO BRASILEIRO DE GEOLOGIA, 29., 1976, Ouro Preto. Anais do 29ํ Congresso Brasileiro de Geologia, p.281-293.

Martins, V.M. 2009. Relação solo-relevo-substrato geológico na planície costeira de Bertioga (SP). Piracicaba, 273p. Tese de Doutorado, Programa de Pós-graduação em Solos e Nutrição de Plantas, Escola Superior de Agricultura Luiz de Queiroz, Universidade de São Paulo.

Mendonça, F. \& Danni-Oliveira, I.M. 2007. Climatologia: noções básicas e clima no Brasil. São Paulo, Oficina dos Textos, $206 \mathrm{p}$.

Mucivuna, V.C., Garcia, M.G.M. \& Del Lama, E.A. 2015. A seleção de geossítios no inventário do Município de Bertioga - SP: critérios e metodologia. In: SIMPÓSIO BRASILEIRO DE PATRIMÔNIO GEOLÓGICO, 3., 2015, Lençóis, Anais do $3^{\circ}$ Simpósio Brasileiro de patrimônio geológico, p. 446-449.

Neves, F.V. 2012. Análise morfodinâmica da evolução da captura fluvial do Rio Guaratuba (Bertioga - SP) através da técnica de datação por Luminescência Opticamente Estimulada (LOE). São Paulo, 96p. Dissertação de Mestrado, Programa de Pós-graduação em Geografia Física, Faculdade de Filosofia, Letras e Ciências Humanas, Universidade de São Paulo.

Oliveira, D. 2003. A captura do Alto Rio Guaratuba: uma proposta metodológica para o estudo da evolução do relevo da Serra do Mar, Boraceia - SP. São Paulo, 105p. Tese de doutorado, Programa de Pós-graduação em Geografia Física, Faculdade de Filosofia, Letras e Ciências Humanas, Universidade de São Paulo.

Oliveira, D. 2010. Capturas fluviais como evidências da evolução do relevo: uma revisão bibliográfica. Revista do Departamento de Geografia, 20: 37-50.

Oliveira, D. \& Queiroz Neto, J.P. 2007. Evolução do relevo na Serra do Mar no Estado de São Paulo a partir de uma captura fluvial. Geousp, 22: 73- 88.

Peiró, D.F. 2012. Status taxonômico de Callichirus major (Say, 1818) sensu lato (Crustacea, Decapoda, Axxida, Callianassidae) da costa brasileira: taxonomia sistemática molecular, biologia populacional e reprodutiva. Ribeirão Preto, 158p. Tese de doutorado, Programa de Pós-graduação em Biologia Comparada, Departamento de Biologia da Faculdade de Filosofia, Ciências e Letras de Ribeirão Preto, Universidade de São Paulo.

Pereira, D., Brilha, J. \& Pereira, P. 2008. Geodiversidade: valores e usos. Disponível em: < http://www.dct. uminho.pt/docentes/pdfs/jb_pereiras.pdf>. Acesso em: 10 out 2015 .

Pereira, R.G.F.A. 2010. Geoconservação e desenvolvimen- 
to sustentável na Chapada Diamantina (Bahia - Brasil). Braga, 318p. Tese de doutorado, Escola de Ciências, Universidade do Minho.

Perrotta, M.M., Salvador, E.D., Lopes, R.C., D’Agostinho, L.Z., Peruffo, N., Gomes, S.D., Sachs, L.L.B., Meira, V.T., Garcia, M.G.M. \& Lacerda Filho, J.V. 2005. Mapa Geológico do Estado de São Paulo. São Paulo, Serviço Geológico do Brasil, escala 1:750.000.

Prochoroff, R. 2014. 0 patrimônio geológico de Ilhabela-SP: estratégias de geoconservação. São Paulo, 176 p. Dissertação de Mestrado, Programa de Pós-gra duação em Mineralogia e Petrologia, Instituto de Geociências, Universidade de São Paulo.

Reverte, F.C. 2014. Avaliação da geodiversidade em São Sebastião - SP, como patrimônio geológico. São Paulo, 208 p. Dissertação de Mestrado, Programa de Pós-graduação em Mineralogia e Petrologia, Instituto de Geociências, Universidade de São Paulo.

Reverte, F.C. \& Garcia, M.G.M. 2016. O patrimônio geológico de São Sebastião-SP: inventário e uso potencial de geossítios com valor científico. Geociências, 35(4): 495-511.

Ribeiro, A.C., Lima, F.L.C., Riccomini, C. \& Menezes, N.A. 2006. Fishes of the Atlantic Rainforest of Boraceia: testimonies of the Quaternary faul reactivation within a Neoproterozoic tectonic province in Southeastern Brazil. Ichthyological Exploration Freshwaters, 17(2): 157-164.

Riccomini, C., Sant'Anna, L.G. \& Ferrari, A.L. 2004. Evolução geológica do Rift Continental do Sudeste do Brasil. In: Mantesso-Neto, V., Bartorelli, A., Carneiro, C.D.R. \& Brito-Neves, B.B. (Orgs.). Geologia do Continente Sul-Americano: Evolução da Obra de Fernando Flávio Marques de Almeida. São Paulo, Beca, p. 383-405.

Rocha, D.R. 2004. Erosão do solo - Núcleo de Pesquisa e Manejo de Solo e Água: Departamento de Ciência do Solo, UFC. Disponível em: <http://www.soloeagua. ufc.br/erosao.pdf> . Acesso em 03 out 2015.

Rossi, M. 1999. Fatores formadores da paisagem litorânea: a Bacia do Guaratuba, São Paulo: Brasil. São Paulo, 168p. Tese de Doutorado. Programa de Pós-graduação em Geografia Física, Faculdade de Filosofia, Letras e Ciências Humanas, Universidade de São Paulo.

Rossi, M \& Queiroz Neto, J.P. 2002. Evolução de Espodopossolo ferrocárbico em Gleissolo háplico no planalto da Serra do Mar, Rio Guaratuba (SP). Revista Brasileira de Ciência de Solo, 26: 407-415.

Santos, E.O. 1965. Características Climáticas. In: Azevedo, A. (Coord.) A Baixada Santista: aspectos geográfi-

Manuscrito 615

Editores: Kátia K. da Rosa \& Paulo A. Souza. cos. São Paulo, Editora da Universidade de São Paulo, p. 95-150.

Santos, P.L.A. 2014. Patrimônio geológico em áreas de proteção ambiental: Ubatuba - SP. São Paulo, 207p. Dissertação de Mestrado, Programa de Pós-graduação em Mineralogia e Petrologia, Instituto de Geociências, Universidade de São Paulo.

Sharples, C. 2002. Concepts and principles of Geoconservation. In: Tasmanian Parks \& Wildlife Service website. Disponível em: <http://www.parks.tas.gov. $\mathrm{au} / \mathrm{geo} /$ conprin/define.html>. Acesso em: 02 set 2014.

SMA/FF. Secretaria de Estado do Meio Ambiente / Fundação Florestal. 2013. Anuário das Reservas Particulares do Patrimônio Natural Instituídas pela Secretaria do Meio Ambiente do Estado de São Paulo. São Paulo, Fundação Florestal, 84p.

SMA/IF. Secretaria do Estado do Meio Ambiente / Instituto Florestal. 2006. Plano de Manejo do Parque Estadual da Serra do Mar. Disponível em: <http:// iflorestal.sp.gov.br/files/2013/03/Plano_Pe_Serra_ do_Mar.pdf>. Acesso em: 10 nov. 2014.

Souza, C.R.G. 2015. The Bertioga Coastal Plain: An Example of Morphotectonic Evolution. In: Vieira, B.C., Salgado, A.A.R \& Santos, L.J.C (Ed.). Landscapes and Landforms of Brazil. Berlin, Springer, p. 115-134.

Suguio, K. 1976. Presença de tubos fósseis de "Callianassa" nas formações quaternárias do litoral paulista e sua utilização na reconstrução paleoambiental. Boletim do Instituto de Geociências-USP, 7: 17-26.

Suguio, K. \& Martin, L. 1978. Quaternary marine formations of the State of São Paulo and southern Rio de Janeiro. In: INTERNATIONAL SYMPOSIUM ON COASTAL EVOLUTION IN THE QUATERNARY, 1., 1978, São Paulo, Publicação Especial, p. 1-55.

Wimbledon, W.A.P. 1996. Geosites: a new conservation initiative. Episodes, 19(3): 87-88.

Wimbledon W.A.P, Andersen S., Cleal, C.J., Cowie, J.W., Erikstad, L., Gonggrijp, G.P., Johansson, C.E., Karis, L.O. \& Suominen, V. 1999. Geological World Heritage: GEOSITES: a global comparative site inventory to enable prioritisation for conservation. Memorie Descritive della Carta Geologica d'Italia, 54: 45-60.

Wimbledon, W.A.P., Ishchenko, A.A., Gerasimenko, N.P., Karis, L.O., Suominem, V., Johansson, C.E. \& Freden. C. 2000. Geosites - an IUGS initiative: science supported by conservation. In: Barettino, D., Wimbledon, W.A.P. \& Gallego, E. (Ed.). Geological Heritage: its conservation and management. Madrid, IGME, $\mathrm{p}$. 69-94. 
